\section{ॠUSGS}

science for a changing world

\section{U. S. DEPARTMENT OF THE INTERIOR}

U. S. GEOLOGICAL SURVEY

Preliminary Report on Deposit Models for

Sand and Gravel in the Cache la Poudre River Valley

(on-line edition)

Open File Report 99-587

By William H. Langer ${ }^{1}$ and David A. Lindsey ${ }^{1}$

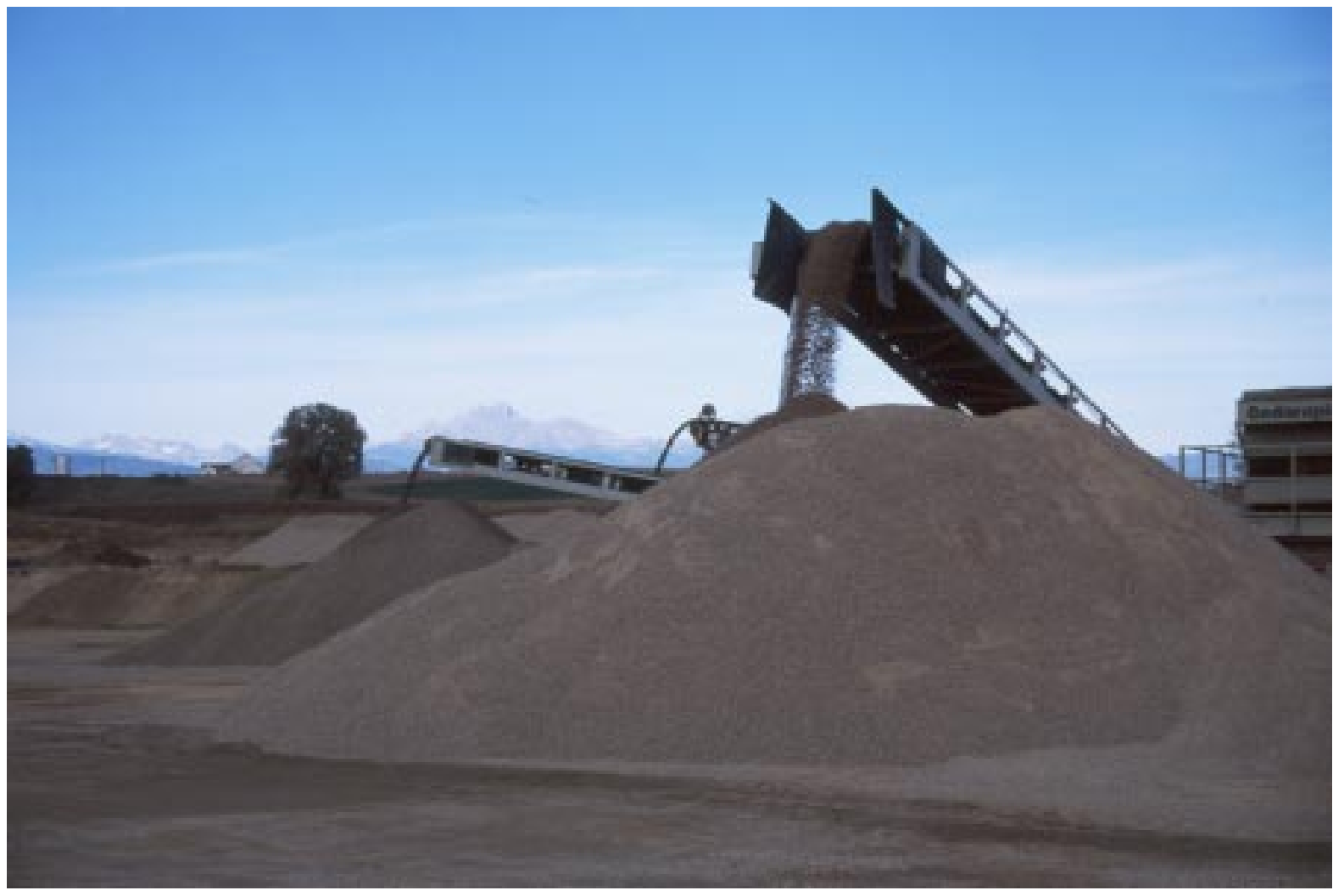

Photo of gravel processing along the Front Range, Colorado

This report is preliminary and has not been reviewed for conformity with U. S. Geological Survey editorial standards or with the North American Stratigraphic Code. Any use of trade, product, or firm names is for descriptive purposes only and does not imply endorsement by the U. S. Government.

${ }^{1}$ U. S. Geological Survey, Denver, Colo., 80225 


\section{Contents}

Abstract 1

Introduction 1

Purpose and Scope 3

Overview of Methods 3

Acknowledgements 3

Geologic Setting 3

General Setting 3

Bedrock Geology 3

Surficial Geology 3

Geomorphic Deposit Models of the Cache la Poudre River Valley 6

Dissected Terraces 7

Geologic Environment 7

Deposit Size 7

Deposit Characteristics 7

Environmental Impacts of Mining 7

Alluvial Fans 7

Geologic Environment 7

Deposit Size 7

Deposit Characteristics 7

Environmental Impacts of Mining 7

High Terraces 7

Geologic Environment 7

Deposit Size 7

Deposit Characteristics 7

Environmental Impacts of Mining 8

Floodplains and Low Terraces 8

Geologic Environment 8

Deposit Size 8

Deposit Characteristics 9

Environmental Impacts of Mining 9

Composition and Quality of Gravel in Floodplains and Low Terraces 9

General Stratigraphy 9

Sampling Plan 12

Sample Processing 12

Particle Size 12

Lithology and Gravel Quality 14

Pebble Shape 17

Pebble Roundness 18

Conclusions 18

References Cited 20 


\section{List of Figures}

Figure 1.-Map showing location of Cache la Poudre River and the study area.

Figure 2.- Map showing location of Cache la Poudre River, sample sites, and sampling plan.

Figure 3.-Valley cross sections showing alluvial deposits of the Cache la Poudre River valley between Fort Collins and Greeley, Colorado.

Figure 4.-Block diagram showing landforms of alluvial deposits of the Cache la Poudre River valley between Fort Collins and Greeley, Colorado.

Figure 5.-Photograph showing large size of clasts at Western Mobile (LaFarge) Taft Hill pit near Fort Collins, Colorado.

Figure 6.-Photograph showing size of clasts at Western Mobile (LaFarge) Greeley West pit near Greeley, Colorado.

Figure 7.- Photograph showing soil and overbank sediment in erosional contact with gravel, Hall Irwin Greeley pit, near Greeley, Colorado.

Figure 8.- Photograph showing changes in texture and color between the two stratigraphic units at the Western Mobile (LaFarge) POE pit near Fort Collins, Colorado.

Figure 9.- Photograph showing details of clay lenses in the upper stratigraphic unit at the Western Mobile (LaFarge) POE pit near Fort Collins, Colorado.

Figure 10.-Photograph showing changes in texture and color between the two stratigraphic units at the Hall Irwin Windsor pit, near Windsor, Colorado.

Figure 11.-Photograph showing changes in texture and color between the upper and lower stratigraphic units at the Western Mobile (LaFarge) $35^{\text {th }}$ Street pit near Greeley, Colorado.

Figure 12.-Photograph showing dirty gravel at Western Mobile (LaFarge) Timnath pit near Fort Collins, Colorado. Figure 13.-Downstream variation in particle size, Cache la Poudre River valley gravel.

Figure 14.-Plot showing ratio of gravel sizes in upper versus lower gravel unit, Cache la Poudre River valley.

Figure 15.-Downstream variation in pebble lithology, Cache la Poudre River valley gravel.

Figure 16.-Downstream variation in gravel quality, Cache la Poudre River valley.

Figure 17.- Plot showing ratio of pebble lithology in upper versus lower gravel unit, Cache la Poudre River valley. Figure 18.-Plot showing ratio of gravel quality in upper versus lower gravel unit, Cache la Poudre River valley. Figure 19.-Zingg diagram showing pebble shape, Cache la Poudre River valley gravel.

Figure 20.- - Histogram showing calculated pebble sphericity, Cache la Poudre River valley gravel.

Figure 21.-Plot showing ratio of pebble shape in upper versus lower gravel unit, Cache la Poudre River valley.

Figure 22.-Downstream variation in pebble roundness, Cache la Poudre River valley gravel.

Figure 23.-Plot showing ratio of pebble roundness in upper versus lower gravel unit, Cache la Poudre River valley.

\section{List of Tables}

Table 1.- Variance components for gravel particle size parameters, Cache la Poudre River. Table 2.- Variance components for gravel lithology and quality, Cache la Poudre River. Table 3.- Variance components for gravel pebble shape, Cache la Poudre River valley.

Table 4.- Variance components for gravel pebble roundness, Cache la Poudre River valley.

\section{List of Appendix Tables}

Table A1.-Particle-size data, sieved gravel samples, Cache la Poudre River valley.

Table A2.-Gravel lithology, Cache la Poudre River valley.

Table A3.-Gravel quality, Cache la Poudre River valley.

Table A4.- Gravel shape, Cache la Poudre River valley.

Table A5.-Gravel roundness, Cache la Poudre River valley.

Table A6.- Sample sites, site symbols, and miles downstream, Cache la Poudre River valley. 


\title{
Open File Report 99-587 \\ Preliminary Report on Deposit Models for Sand and Gravel in the Cache la Poudre River Valley
}

\author{
By William H. Langer and David A. Lindsey
}

\begin{abstract}
The stratigraphy, sedimentary features, and physical characteristics of gravel deposits in the Cache la Poudre River valley were studied to establish geologic models for these deposits. Because most of the gravel mined in the valley is beneath the low terraces and floodplain, the quality of these deposits for aggregate was studied in detail at eight sites in a 25.5-mile reach between Fort Collins and Greeley, Colorado. Aggregate quality was determined by field and laboratory measurements on samples collected under a consistent sampling plan.

The Broadway terrace is underlain by Pleistocene alluvium and, at some places, by fine-grained wind-blown deposits. The Piney Creek terrace, low terraces, and floodplain are primarily underlain by Holocene alluvium. Pleistocene alluvium may underlie these terraces at isolated locations along the river. Gravels beneath the Piney Creek terrace, low terraces, and floodplain are divisible into two units that are poorly distinguishable at the upstream end of the study area, but are readily distinguishable about 7 miles downstream. Where distinguished, the two gravel units are separated by a sharp, locally erosional, contact. The upper gravel is probably of Holocene age, but the lower gravel is considered to be Holocene and Pleistocene.

The primary variation in particle size of the gravels beneath the floodplain and low terraces of the Cache la Poudre River valley is the downstream decrease in the proportion of particles measuring 3/4 inch and larger. Above Fort Collins, about 60 pct of the gravel collects on the $3 / 4$ inch sieve, whereas about 50 pct of gravel collects on the same sieve size at Greeley. For 1.5-inch sieves, the corresponding values are about 50 pct for Fort Collins and only about 30 pct for Greeley. Local differences in particle size and sorting between the upper and lower gravel units were observed in the field, but only the coarsest particle sizes appear to have been concentrated in the lower unit.

Field measurements of aggregate quality, pebble lithology, and shape show little significant downstream variation. Pebble lithology is about 25 percent granite; 48 percent pegmatite; 5-7 percent each of gneiss, quartz, and quartzite; and minor amounts of diabase, schist, volcanic porphyry, and sandstone. Among the rock types, only the volcanic porphyries might be reactive with Portland cement.

Pebble shape is dominantly equidimensional with a tendency to form thick, disc-shaped particles. Disc-shaped and spherical particles comprise about 39 percent and 31 percent of the pebble-size fraction, respectively. Rod and blade shapes comprise about 18 and 12 percent of the pebble-size fraction, respectively. The relatively large proportion of equidimensional particles in the Cache la Poudre may be due to the small proportion of layered gneiss in gravel. Pebbles having axial ratios less than 0.5 , which might be structurally weak, are rare.

The two gravel units show subtle local differences and evidence for derivation of the younger gravel from the older gravel. At many sites, the upper gravel unit tends to contain more quartz plus quartzite, has poorer physical quality, and contains more angular pebbles than the lower gravel. Weathering, followed by transport in the river, might be expected to concentrate quartz and quartzite, degrade physical quality, and break pebbles into angular fragments. This conclusion is consistent with local evidence of an erosional contact between the two gravel units.
\end{abstract}

\section{INTRODUCTION}

Infrastructure, such as roads, buildings, and airports, are built and maintained by use of large quantities of natural aggregate. About 80 percent of the aggregate produced in Colorado is sand and gravel, which comes from floodplains and terraces along stream and river valleys, or occasionally from high dissected terraces and alluvial fans along the mountain front. About 20 percent of Colorado aggregate production is crushed stone, which comes from rock quarries located mostly in the mountains or, in a few cases, from buttes or mesas on the plains.

As the Front Range urban areas expand, the very growth that demands aggregate resources also precludes its development. Other competitive land uses have a higher value than aggregate resources. For example, gravel cannot be mined from under a subdivision. Growth in Fort Collins, Greeley, and the corridor between those cities, has precluded some aggregate development. In addition, zoning and environmental restrictions can further restrict development of natural resources. If aggregate resources are to remain economically available, current resource information must be available for use in well-reasoned decisions about future land use. The failure to plan for the protection and extraction of aggregate resources may result in increased consumer cost, environmental damage, and an adversarial relationship between industry and the public.

The gravel deposits of the Cache la Poudre valley between Fort Collins and Greeley (Figs. 1 and 2) are the principal source of aggregate for urban development in the valley. This report describes the sand and gravel deposits of the Cache La Poudre valley from Fort Collins 


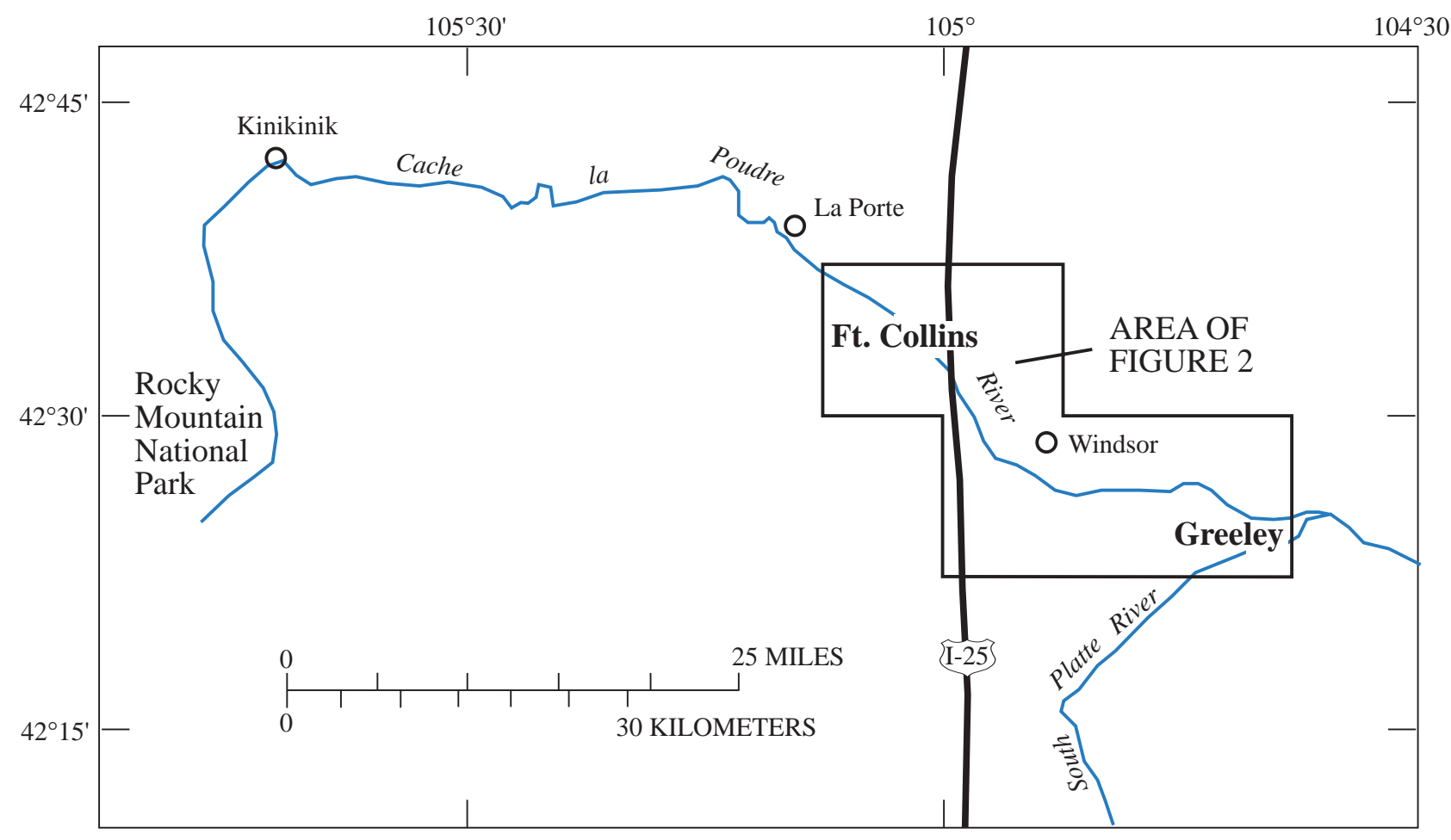

Figure 1.-Map showing location of Cache la Poudre River and the study area.

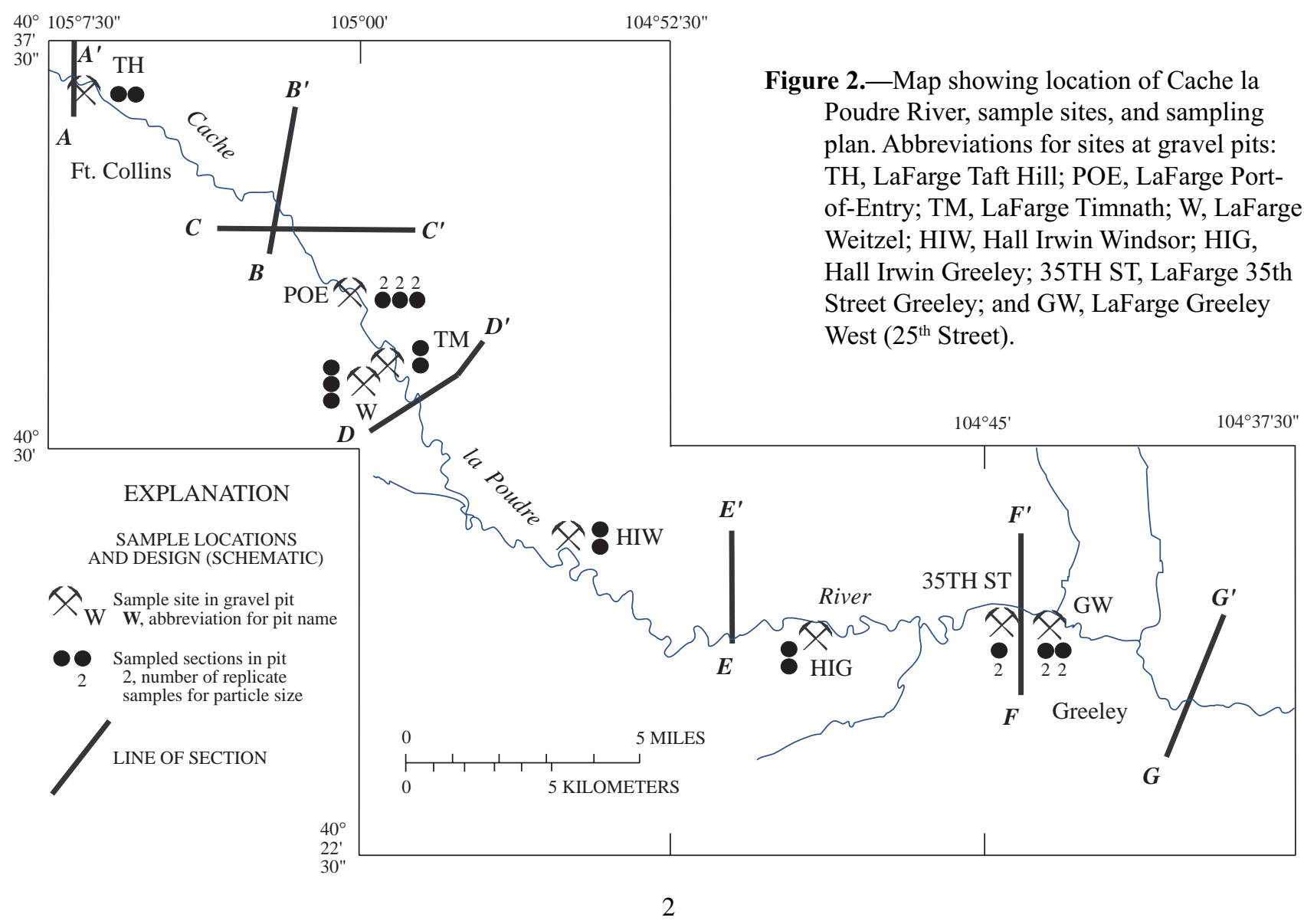


eastward to Greeley to provide information for appropriate utilization of this important local resource.

\section{Purpose and Scope}

The U.S. Geological Survey (USGS), in collaboration with the Colorado Geological Survey (CGS), the National Stone Association, and other cooperators, is developing information, defining tools, and demonstrating ways to evaluate aggregate resources (crushed stone, sand, and gravel) in the Front Range Urban Corridor. This report addresses one project task, to prepare deposit models for aggregate resources.

Floodplains and low terraces are the principal sources of aggregate that are developed in the Cache la Poudre River valley. Sand and gravel also underlie small high terraces and alluvial fans along the Cache la Poudre River, but commonly are not used as specification aggregate because of inferior quality. This report describes deposit models for all the types of gravel deposits along the Cache la Poudre River, but focuses on a model for the floodplain low terraces and the description of those deposits.

The stratigraphy and sedimentary structures of the sand and gravel deposits in the Cache la Poudre River valley were studied to establish a framework for the assessment of the quantity and quality of the gravel resources. Although the regional distribution of the gravel resources is well-established (Colton and Fitch, 1974; Schwochow and others, 1974b; Shelton and Rogers, 1987), information on the stratigraphy and quality of gravel is generally unavailable. Some subsurface information includes postings of reconnaissance data on gravel thickness, particle size, and pebble composition (Colton and Fitch, 1974; Schwochow and others, 1974b) and well and test hole logs of surficial deposits (Schneider and Hershey, 1961).

\section{Overview of Methods}

New and existing data on the subsurface of the Cache la Poudre River valley were collected and synthesized to establish a new stratigraphic framework. Well and test hole logs (Schneider and Hershey, 1961) were compiled into seven cross sections showing the stratigraphy of valley deposits. Stratigraphic relationships and sedimentary features of gravel beneath the floodplain and terraces were mapped and described from exposures at eight gravel pits (Fig. 2) in the Cache la Poudre valley.

Samples for measurement of particle size and determination of pebble lithology, shape, roundness, physical quality, and chemical quality were collected from vertical trenches taken at one to three locations and from one or two horizons at each of eight gravel pits. Sample spacing was guided by results of earlier studies (Lindsey and Shary, 1997; Lindsey and others, 1998a and 1998b). Each sample was processed in the field by dry sieving and weighing size fractions. The 3/4-1.5 inch pebble fraction was reserved for lithologic identification and laboratory measurements as described in Lindsey and Shary (1997).

\section{Acknowledgements}

We thank the employees of LaFarge (previously known as Western Mobile) and Hall Irwin for granting access to company gravel pits and for sharing their knowledge of individual gravel deposits and mining operations. B. F. Arbogast, U. S. Geological Survey, took the title page photograph.

\section{GEOLOGIC SETTING \\ General Setting}

The Cache la Poudre River is in north-central Colorado and heads on the Continental Divide in Rocky Mountain National Park (Fig. 1). The river flows northward to Kinikinik, then eastward through the mountains, foothills, and hogback, where it emerges on the Great Plains at La Porte. From La Porte, the river flows southeastward through Fort Collins, past Windsor; it joins the South Platte River east of Greeley. This study is restricted to the lower part of the river from the mountain front to its confluence with the South Platte River.

\section{Bedrock Geology}

The surficial deposits in the study area were deposited on two formations of Lower Cretaceous age, the Pierre Shale and the overlying Fox Hills Sandstone. The best location to view the contact between these formations is approximately five miles east of Windsor at the escarpment along the south side of the valley of the Cache la Poudre River. From that location westward, the Cache la Poudre River alluvium lies directly on various members of the Pierre Shale. For the most part, the Pierre Shale is shale, claystone, and sandy siltstone. The Fox Hills Sandstone consists of well-sorted, medium-grained, thick-bedded sand.

The surficial deposits are sufficiently thin that, upstream from Windsor, the excavation of gravel generally extends to bedrock (Fig. 3 - Sections A-A' through E-E'). Downstream from Windsor, the bedrock valley deepens and the deposits thicken to where excavation of aggregate commonly stops before reaching bedrock (Fig. 3 - Sections F-F', G-G'), except where pits are located along the margins of the valley.

\section{Surficial Geology}

The surficial geologic units of the study area are mostly Quaternary in age. The mountainous part of the study area was exposed to repeated glaciation. Glacial activity provided large amounts of sediment and meltwater to transport the sediment to the lower part of the Cache la Poudre River between Fort Collins and Greeley. Glacial advances in the mountainous headwaters of the Cache la Poudre River correspond to geomorphic cycles in the lower part of the river. Each geomorphic cycle consists of downward stream cutting, sideward 




FEET ABOVE SEA LEVEL

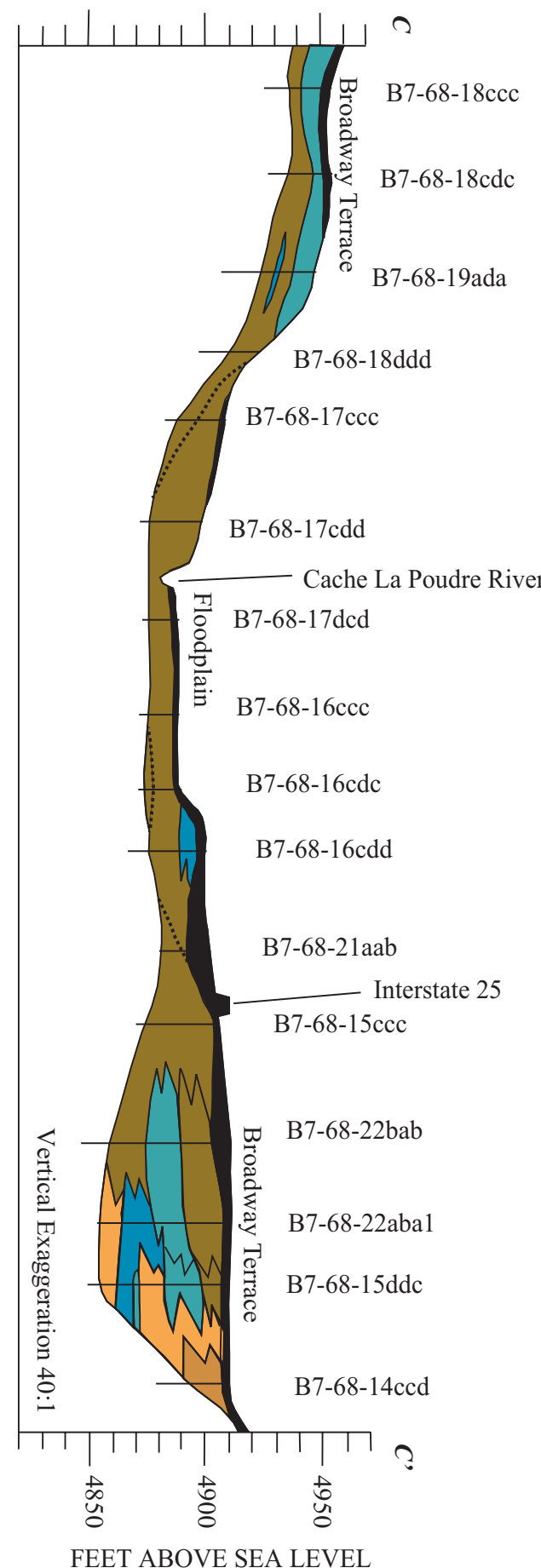

FEET ABOVE SEA LEVEL

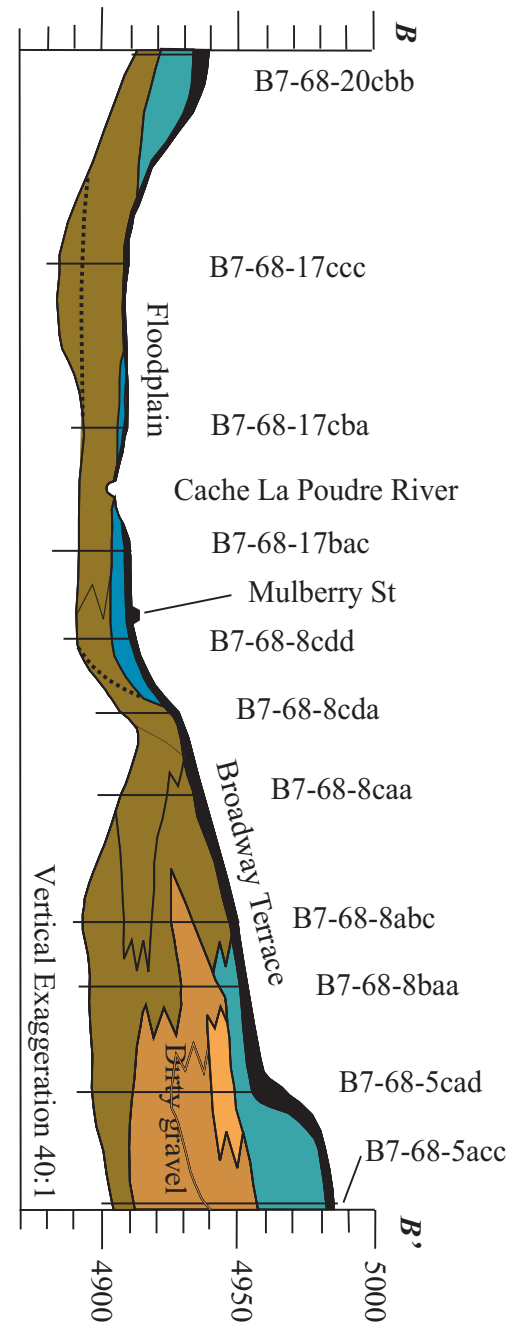

FEET ABOVE SEA LEVEL
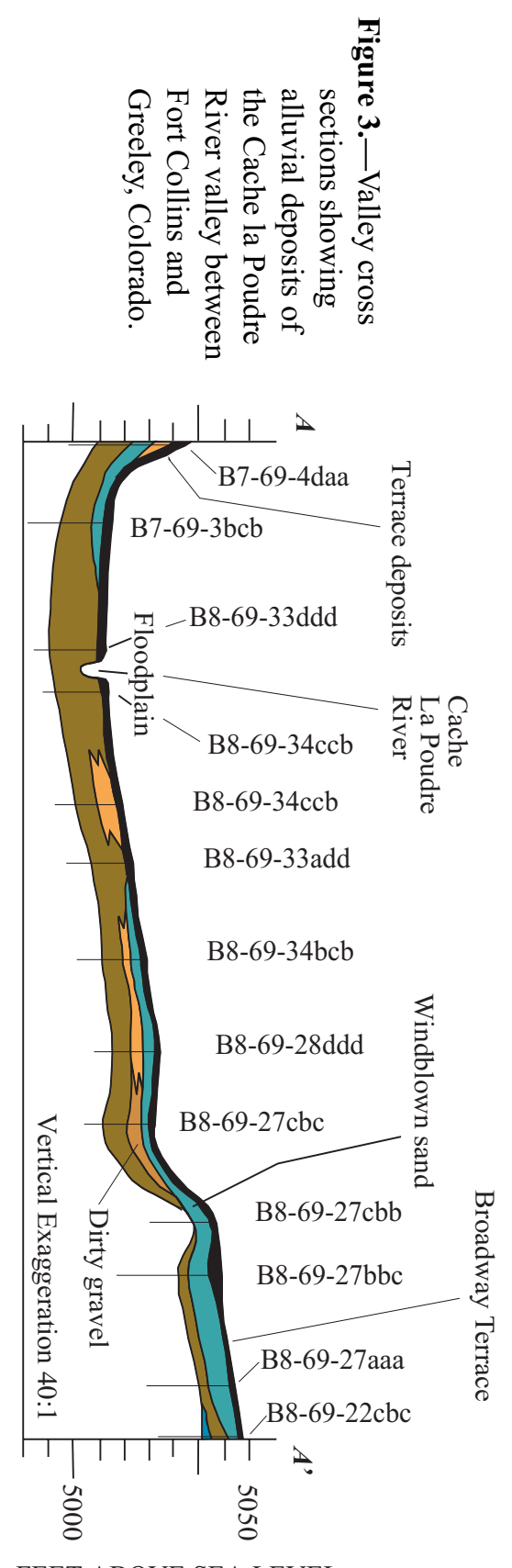

FEET ABOVE SEA LEVEL 

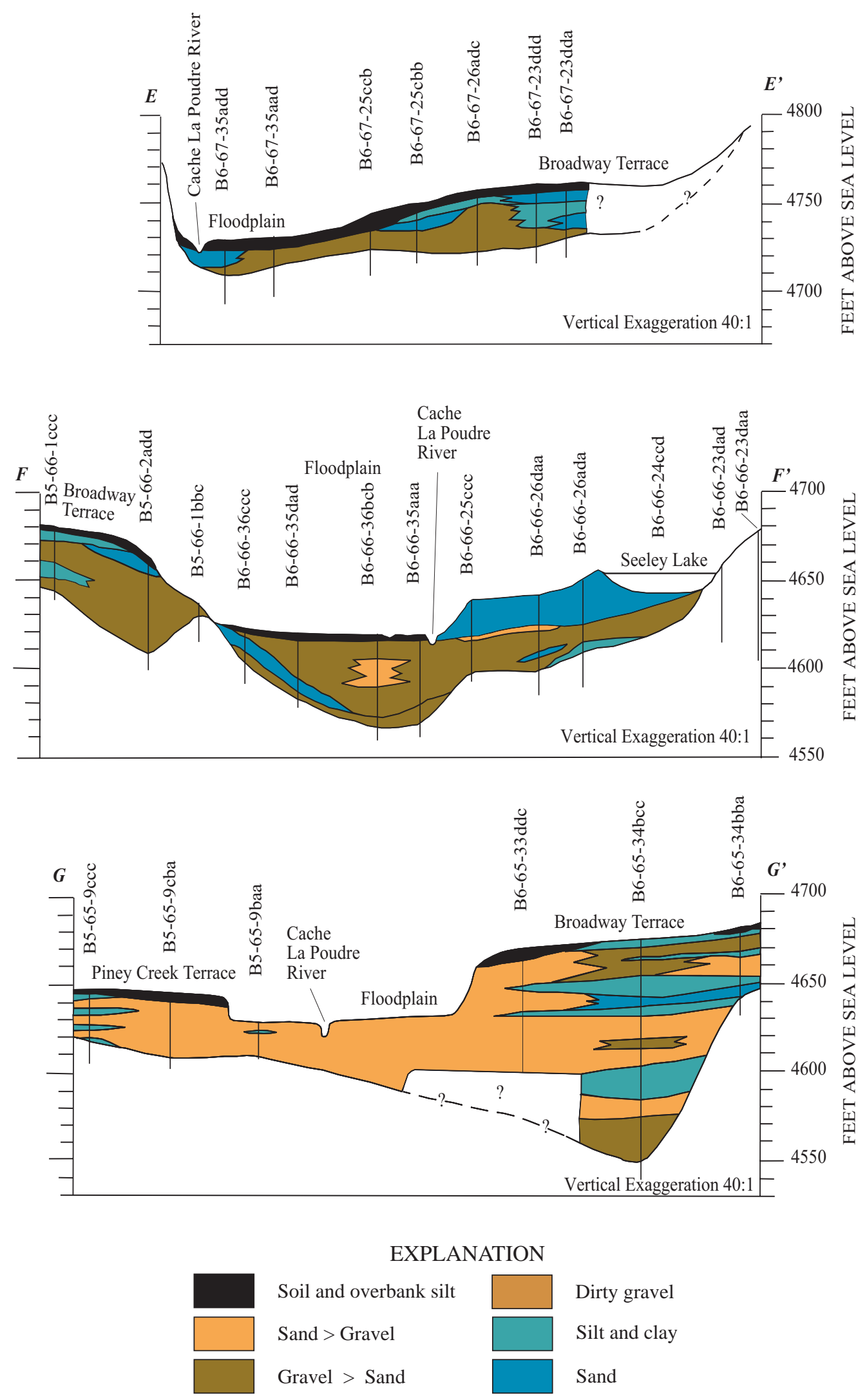

Base of Holocene (estimated)

Figure 3 (continued). - Valley cross sections showing alluvial deposits of the Cache la Poudre River valley between Fort Collins and Greeley, Colorado. 
stream cutting, alluviation, wind erosion and deposition, and soil formation (Scott, 1963). Each cycle formed a separate stream terrace. Four terraces, or cycles, are recognized in the study area. They are, from oldest to youngest, the Verdos Alluvium, Louviers Alluvium, Broadway Alluvium, and the Piney Creek Alluvium. A fifth, incomplete cycle, is represented by the modern floodplain, referred to as the post-Piney Creek Alluvium (Colton, 1978). Other terraces mapped by Scott (1963) along the Platte River south of the study area have not been mapped along the Cache la Poudre River.

\section{GEOMORPHIC DEPOSIT MODELS OF THE CACHE LA POUDRE RIVER VALLEY}

Deposit models contain information about 1) geologic environment, 2) deposit size, 3) deposit characteristics, and 4) environmental impacts from mining (Cox and others, 1986). Deposits are defined as entire geomorphic units such as alluvial terraces along streams (Bliss, 1993). Geologic environment refers to the present geologic (and geomorphic) setting, which are the product of both the sedimentary environment in which the deposit formed and the subsequent geologic history of the site. The area and thickness of a deposit describe size (volume). Deposit characteristics include sedimentary features and physical properties that are relevant to aggregate quality or suitability, such as particle size and composition. In this report, only impacts of mining on the geologic environment, such as the water table, are considered. Engineering impacts such as noise and dust are beyond the scope of this report.

Working models of sand and gravel deposits of the Front Range Urban Corridor have been prepared by preliminary analysis of three kinds of available data: 1) deposit maps showing distribution of sand- and gravelbearing units, 2) subsurface sections, based on borehole logs showing depth and thickness of sand, gravel, and other sediment, and 3) compilations of particle size and composition, which are useful for assessing aggregate quality or suitability. Using these data, the geologic environment of a deposit can be identified and, consequently, the deposit can be assigned to the appropriate model. Deposit characteristics can be identified by integrating data on particle size and composition with lithologic maps and subsurface sections. Statistical models of deposit size (volume) can be prepared from dimensions of individual deposits shown on maps and cross-sections.

Lindsey (1997) described five general geomorphic deposit models in the Colorado Front Range that reflect the map units utilized by Schwochow and others (1974a). These five models are dissected fans, high dissected terraces, high terraces, low terraces and modern floodplains, and eolian sand. Lindsey and others (1998a) prepared a detailed stratigraphic model of gravel beneath the low terraces and modern floodplain of the South Platte River valley between Denver and Brighton, Colorado. They then used the new stratigraphic model to guide sampling and analysis of gravel deposits for aggregate quality (Lindsey and others, 1998b). Deposit models, field sampling methods, laboratory methods, and statistical techniques for estimating aggregate quality in gravel

Figure 4.-Block diagram showing landforms of alluvial deposits of the Cache la Poudre River valley between Fort Collins and Greeley, Colorado.

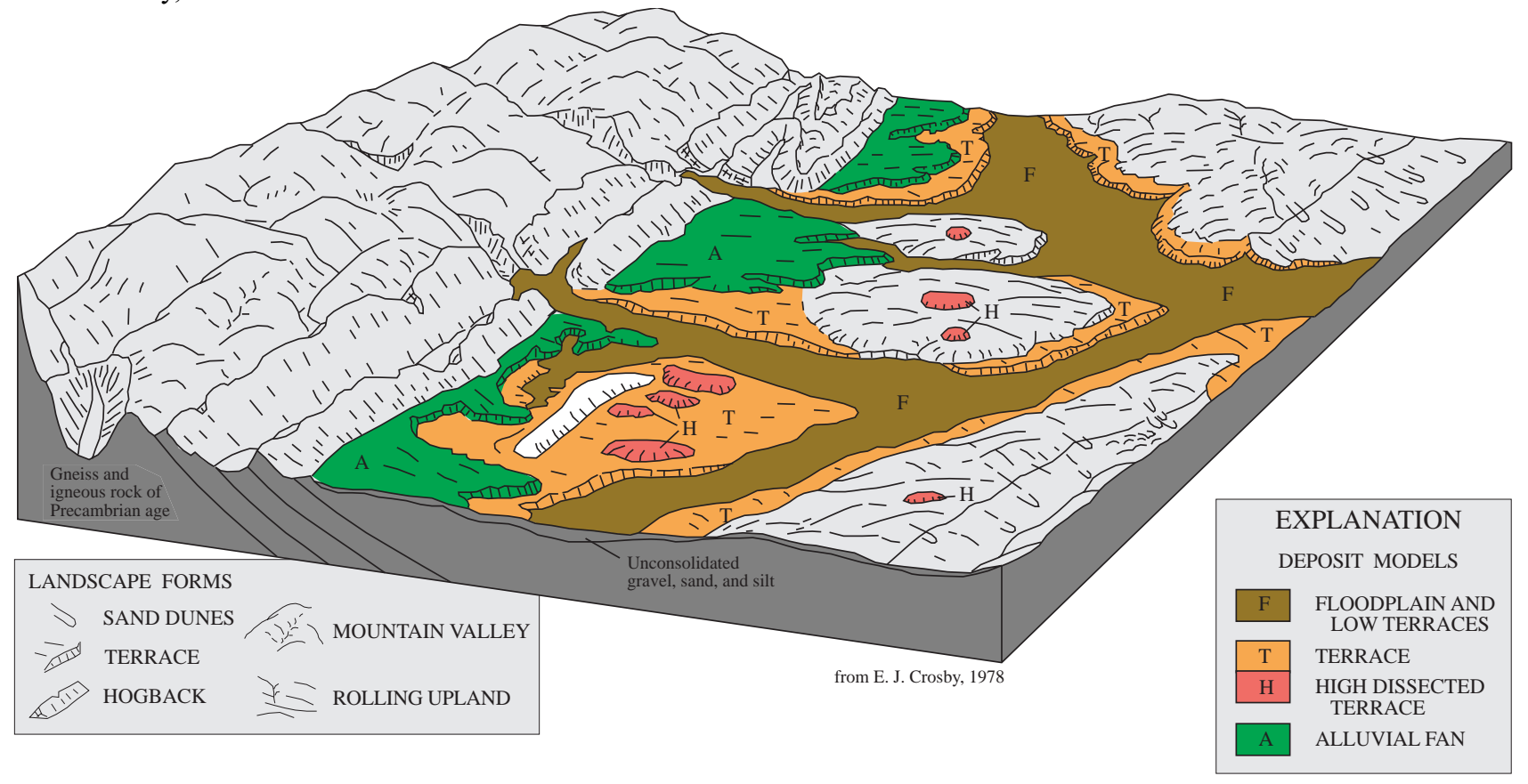


deposits of the Front Range Urban Corridor were summarized by Lindsey and Langer (1988; 1999). Their methods were used for the present study. Langer and others (1999) illustrated the use of deposit model data for decision-making.

Four gravel deposit models are defined for the Cache la Poudre River valley. These models correspond to four classes of landforms underlain by gravel deposits (Fig. 4) that were mapped by Schwochow and others (1974a) in the Cache la Poudre River valley between Fort Collins and Greeley, Colorado. From the highest (oldest) to lowest (youngest) the major landforms are dissected terraces, alluvial fans, high terraces, and floodplains and low terraces (Lindsey, 1997).

\section{Dissected Terraces}

Geologic Environment-Dissected terraces (referred to as Upland Deposits by Schwochow and others, 1974a), occur as isolated erosional remnants on hills overlooking the Cache la Poudre River valley. The deposits were once nearly continuous surfaces of floodplain alluvium (Verdos and Louviers Alluviums) of the Pleistocene Cache la Poudre River. The surfaces commonly are 150 to 175 feet above the modern Cache la Poudre River floodplain.

Deposit Size - Deposits occupy small isolated areas south of Greeley and north of Windsor. The dissected terrace deposits are up to 20 feet thick, but commonly between 10 and 15 feet thick.

Deposit Characteristics-Deposits commonly consist of pebble, cobble, and boulder gravel and sand. Thick, well-developed soil profiles contain much clayey material. Thick caliche (calcium carbonate) locally cements the gravel. The gravel-size clasts are mostly weathered, partly decomposed, and coated with caliche.

Environmental Impacts of Mining-Sand and gravel mining in dissected uplands commonly does not penetrate the water table. The aggregate is dry and can be extracted by using conventional earth-moving equipment. The impacts from excavating aggregate from a dry pit are commonly engineering related.

\section{Alluvial Fans}

Geologic Environment-The alluvial fans occur beneath high surfaces isolated from, and overlooking, the Cache la Poudre River. The deposits once underlay a nearly continuous surface of alluvial fans (Slocum Alluvium of Pleistocene age) spreading from the mountain eastward onto the Great Plains. The surfaces commonly are 50 to 100 feet above the Cache la Poudre River floodplain.

Deposit Size-Deposits occupy large areas in, south, and west of Fort Collins. The alluvial fan deposits are as much as 20 feet thick.

Deposit Characteristics-Deposits commonly consist of pebble, cobble, and boulder gravel and sand. Thick, well-developed soil profiles contain much clayey material. Thick caliche (calcium carbonate) locally may cement the gravel. Gravel-size clasts are mostly weathered, partly decomposed, and coated with caliche.

Environmental Impacts of Mining - Sand and gravel mining in alluvial fans commonly does not penetrate the water table. The aggregate is dry and can be extracted by using conventional earth-moving equipment. The impacts from excavating aggregate from a dry pit are commonly engineering-related.

\section{High Terraces}

The alluvial stratigraphy of the Cache la Poudre River valley is delineated on the set of cross sections (Fig. 3 ). For the most part, the cross sections show two ages of deposits: the older, Pleistocene alluvium underlying the high (Broadway) terrace, and the younger, Holocene alluvium underlying the floodplain and the low (Piney Creek) terrace (described below). The alluvial deposits of Holocene age are separated on the cross sections (Figs. $3 \mathrm{~B}, 3 \mathrm{C}$, and 3D) from the underlying deposits of Pleistocene age by a dotted contact. The separating contact is inferred from textural changes noted in drill logs, or from relief shown on topographic maps. Age classification of deposits is from Colton (1978).

Geologic Environment-High terraces are intermediate in elevation between the dissected terraces and alluvial fans and the low terraces and floodplains (Fig. 3, section D-D'). The terraces were once nearly continuous surfaces of floodplain alluvium (Broadway Alluvium) of a late Pleistocene age Cache la Poudre River. Terrace surfaces are about 15 to 40 feet above the present Cache la Poudre floodplain.

Deposit Size — High terraces form large contiguous surfaces along most of the north side of the river, and on both the north and south sides of the river at Greeley. Gravel deposits beneath the Broadway terrace commonly are 50 feet thick (Fig. 3, sections B-B' and C-C'); near Greeley, they are over 100 feet thick (section G-G'). The thickest deposits occur on the north side of the Cache la Poudre River.

Deposit Characteristics - The Broadway alluvium, which is a highly variable deposit, underlies the high terraces. The deposits contain coarse, high quality gravel that constitutes a major aggregate resource, but in places they contain weathered gravel that is less desirable as a source of aggregate. The deposits are well to poorly sorted and well to poorly layered. Deposits can contain significant amounts of very fine sand, silt and clay occurring as layers within the deposits (Fig 3, sections C$\mathrm{C}^{\prime}$ and $\mathrm{G}-\mathrm{G}^{\prime}$ ), or mixed with sand and gravel resulting in dirty gravel (section B-B'). The clasts range in size from boulders to pebbles and generally decrease in size downstream.

Wind-blown sand, silt, and clay cover much of the Broadway terrace between Fort Collins and Greeley (Fig. 3, section F-F'). At some places the thickness of windblown deposits is as much as 25 feet. Near Fort Collins the wind-blown deposits extend onto the low 
terraces and floodplain deposits as well (Fig. 3, sections A-A', B-B', and C-C').

Environmental Impacts of Mining-Sand and gravel mining in high terraces may or may not penetrate the water table, depending on local conditions. If the excavation does not penetrate the water table, the aggregate is dry and can be extracted by using conventional earth-moving equipment. The impacts from excavating aggregate from a dry pit are commonly engineering related.

If the excavation penetrates the water table and the pit is mined dry, water must be pumped or otherwise removed from the pit because the pit will become a discharge point. Ground water discharge may lower the water table near the operation and, in turn, impact nearby wells. In highly permeable deposits, slurry walls might be necessary to isolate the pit from the water table. Water removed during dewatering can be returned to nearby streams; these streams may recharge the aquifer downstream from the pit. The impacts to the water table from dewatering can be monitored by use of observation wells.
In some situations where the sand and gravel pits penetrate the water table, the pit may not be able to be drained, or the operator may prefer to extract the sand and gravel by using wet mining techniques. Material may be excavated by using draglines, clamshells, bucket and ladder, or hydraulic dredges. In semiarid climates such as the Front Range Urban Corridor, evaporation from water in pits can lower the water table. Monitoring wells installed around the pit and stream gauges can be used to observe effects on the water table.

\section{Floodplains and Low Terraces}

Geologic Environment-The low terraces (postPiney Creek Alluvium of Holocene age) and the modern floodplain form the lowest surfaces in the Cache la Poudre River valley. Commonly the lowermost terrace (post-Piney Creek) lies at elevations only a few feet higher than the modern floodplain, so that they cannot be distinguished on most topographic maps.

Deposit Size-For most of the reach from Fort Collins to Greeley the floodplains and low terraces occupy about half the width of the valley as defined by all

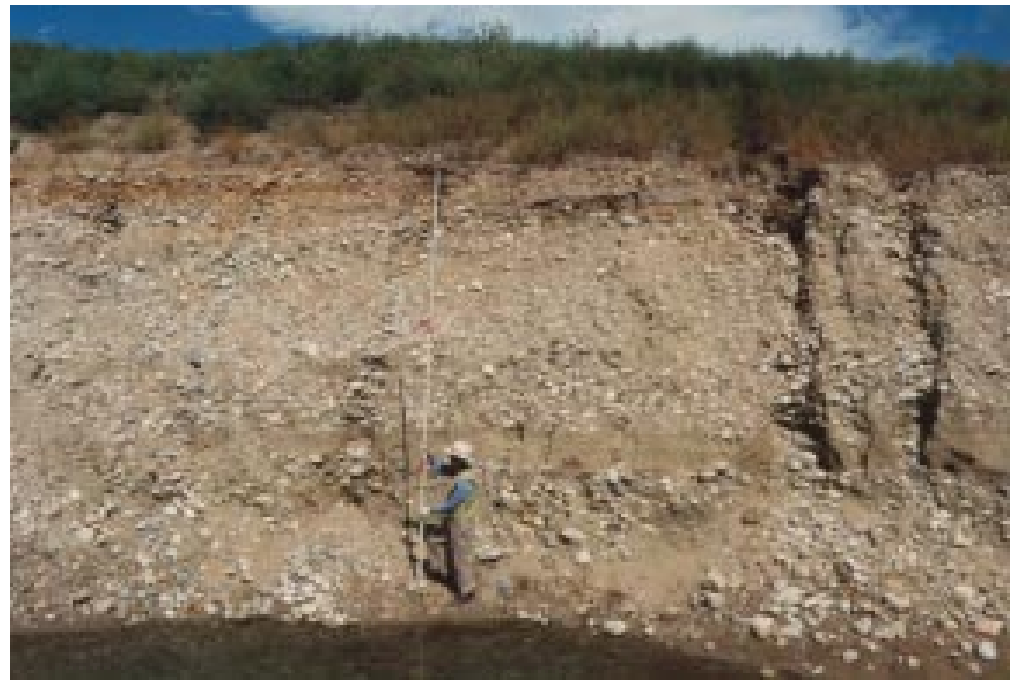

Figure 5.-Photograph showing large size of clasts at Western Mobile (LaFarge) Taft Hill pit near Fort Collins, Colorado.

Figure 6.- Photograph showing size of clasts at Western Mobile (LaFarge) Greeley West pit near Greeley, Colorado. Clast size is much smaller than that upstream at Haft Hill pit.

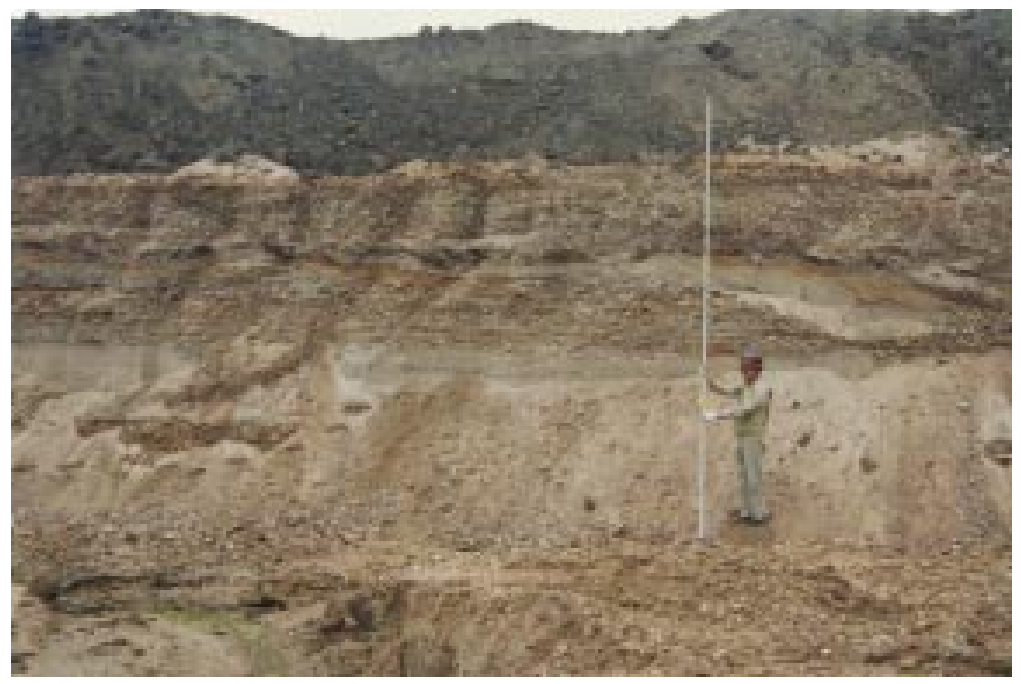


alluvial landforms. The deposits range in thickness from about 20 feet near Fort Collins to about 50 feet near Greeley.

Deposit Characteristics-Deposits are well sorted and well layered. Near Fort Collins the clasts range in size from pebbles to boulders (Fig. 5). Near Greeley (Section G-G') the deposits do not contain boulder-sized clasts (Fig. 6). Overburden, consisting mostly of overbank silt, clay, and very fine sand, is generally thin.

Environmental Impacts of Mining-If excavation penetrates the water table and the pit is mined dry, water will be pumped or otherwise removed from the pit. The pit will become a discharge point, and this ground water discharge may lower the water table near the operation and, in turn, impact nearby wells. In highly permeable deposits, slurry walls might be necessary to isolate the pit from the water table. Water removed during dewatering can be returned to nearby streams, which may serve to recharge the aquifer downstream from the pit. The impacts to the water table from dewatering can be monitored by use of observation wells.

In some situations where the sand and gravel pits penetrate the water table, the pit may not be able to be drained, or the operator may prefer to extract the material by using wet mining techniques. Material may be excavated by using draglines, clamshells, bucket and ladder, or hydraulic dredges. The greatest potential impact of mining a wet pit occurs when the pit is located on an active floodplain. Cut-offs and avulsions of a stream during floods may cause flooding and (or) capture of the pit.

Changes in stream channel geometry have been documented where sand and gravel have been mined directly from stream channels in rivers in northern California (Kondolf, 1998). However, in-stream channel mining commonly is not conducted in the Front Range Urban Corridor. Even so, some streams, in particular those underlain by large gravel layers deposited under conditions other than those prevailing at the present, may support gravel extraction with no serious environmental impacts. Jiongxin (1996) described such a situation on the Hanjiang River in China where downcutting stopped when coarse bed material was reached. The Cache la Poudre is a similar situation, where coarse gravel of glacial origin underlies modern stream deposits.

Sand and gravel pits located on active floodplains may be captured by cut-offs and avulsions of streams during floods. Pit capture can result in trapping of bedload. Levees or dikes may protect floodplain pits from flooding, and can keep bedload in the channel. Dikes prepared with engineered armored spillways at low points allow controlled flooding and can help prevent pit capture (Norman and others, 1998).

\section{COMPOSITION AND QUALITY OF GRAVEL IN FLOODPLAIN AND LOW TERRACES}

The floodplain and low terraces are underlain by coarse gravel, which currently is the most exploited aggregate resource in the Cache la Poudre River valley. Therefore, detailed studies were conducted for this deposit model.

\section{General Stratigraphy}

From top to bottom, the floodplain and low terraces are underlain by 1) soil and overbank deposits (commonly 3-5 feet thick) and 2) two poorly defined gravel units beneath the overbank deposits. The soils and overbank deposits commonly consist of gray to brownish-gray silt, clay, and sand, and in places contain small amounts of gravel (Fig. 7). The contact between the soil and overbank unit and the underlying sand and gravel deposit commonly is a sharp erosional contact that is marked by an abrupt change in grain size from clay, silt and sand to sand and gravel.

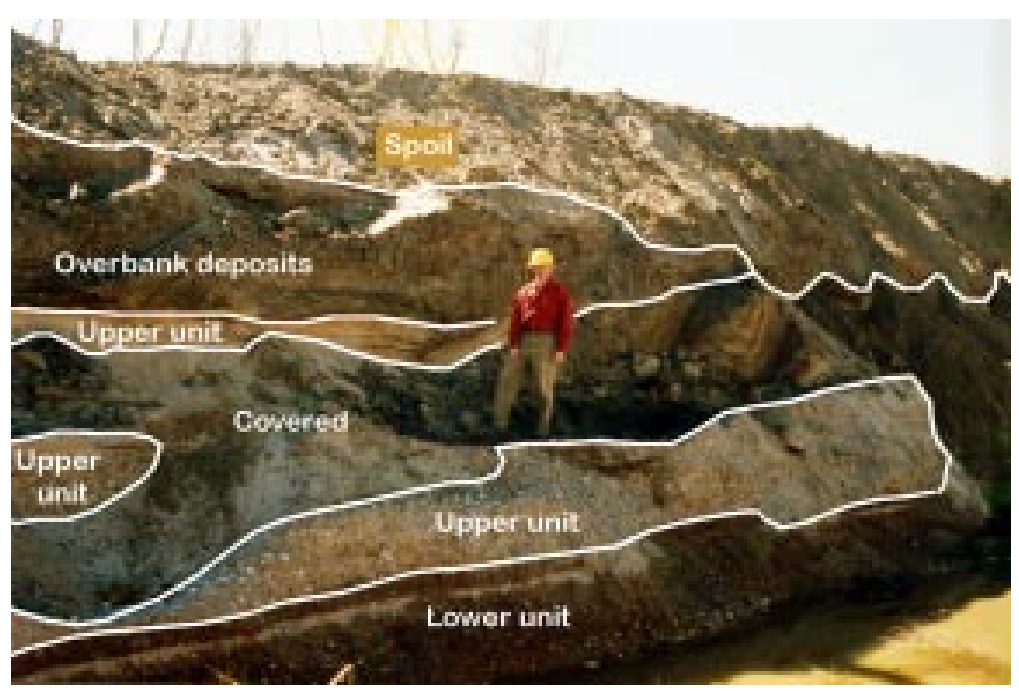

Figure 7.-_Photograph showing soil and overbank sediment in erosional contact with gravel, Hall Irwin Greeley pit, near Greeley, Colorado. 


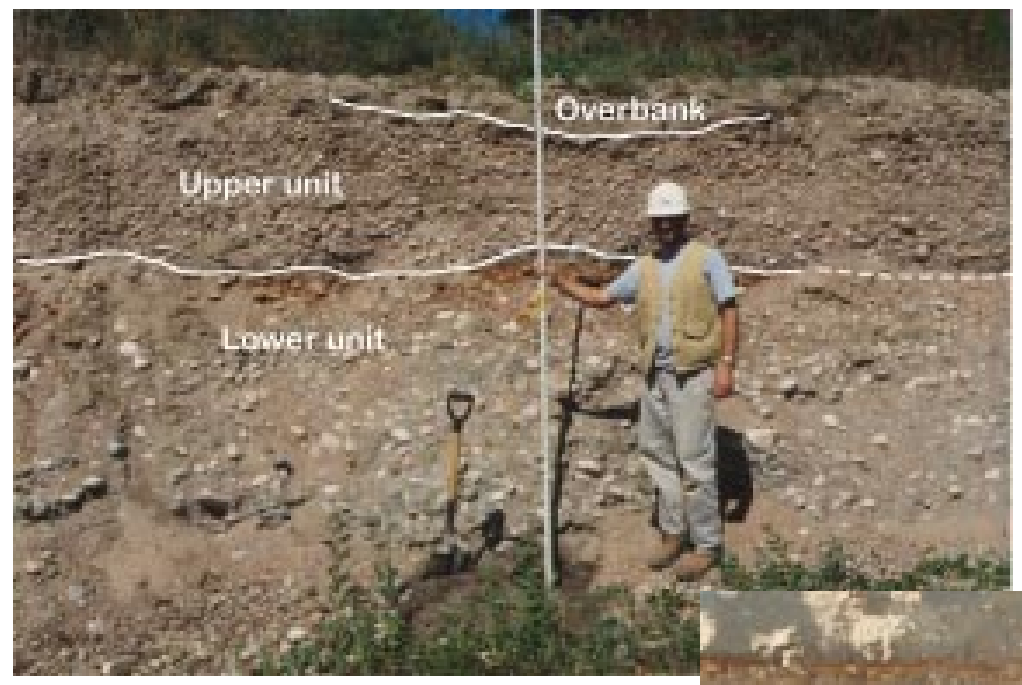

Figure 8.- Photograph showing changes in texture and color between the two stratigraphic units at the Western Mobile (LaFarge) POE pit near Fort Collins, Colorado.

Figure 9.- Photograph showing details of clay lenses in the upper stratigraphic unit at the Western Mobile (LaFarge) POE pit near Fort Collins, Colorado.
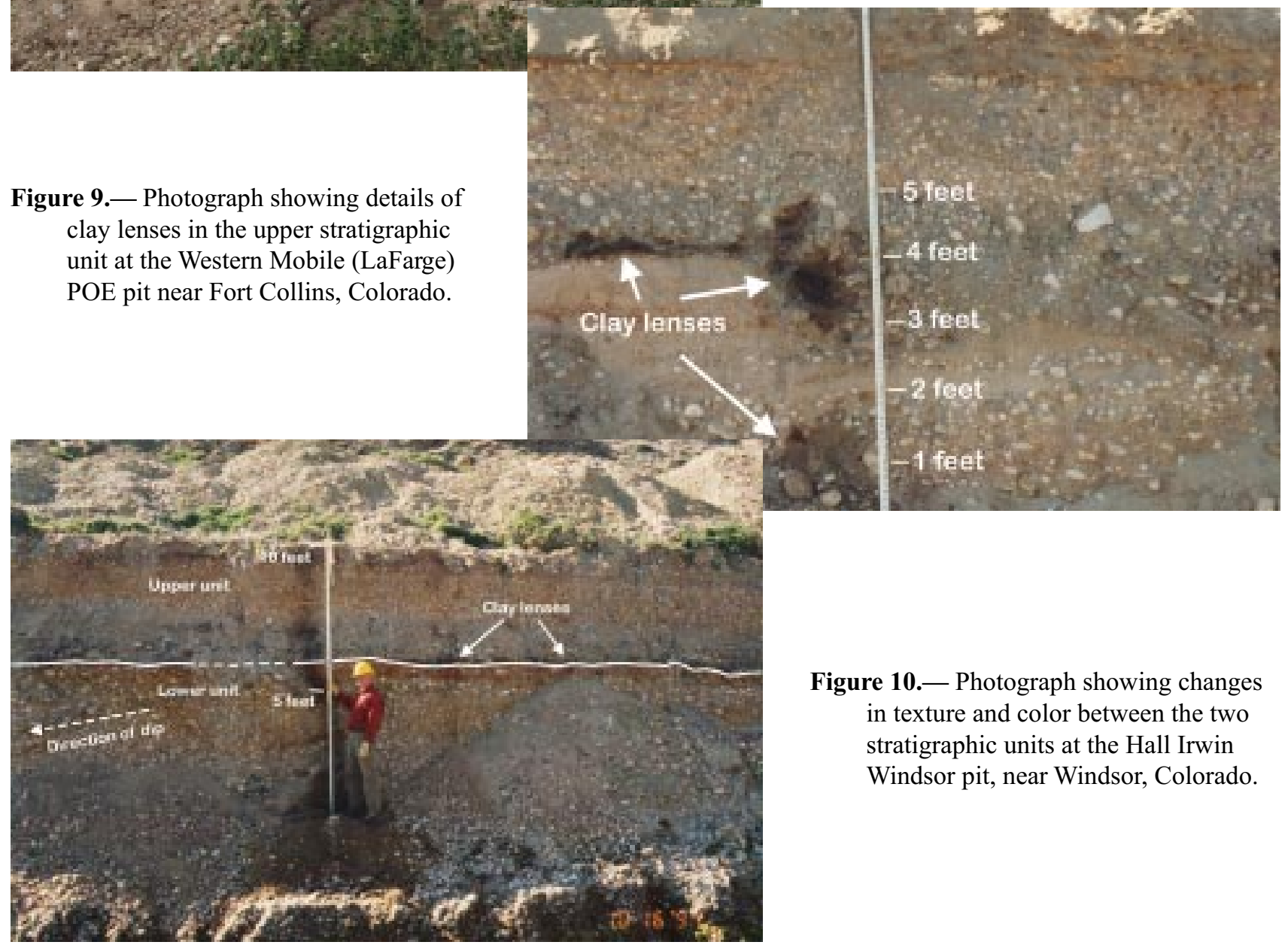

Two gravel units can be distinguished beneath the floodplain and low terraces of the Cache la Poudre River valley, but they are not everywhere visible and their appearance is not consistent from one locality to the next. Two units can not be distinguished upstream, at the Western Mobile (LaFarge) Taft Hill pit (Fig. 5), where the entire section of alluvial gravel is very coarse.

Two poorly defined gravel units can be observed at the Western Mobile (LaFarge) POE pit (Fig. 8), located approximately 7.1 miles downstream from the Taft Hill pit. The contact commonly is marked by changes in texture and color. The upper unit contains irregular masses and lenses of organic-rich clay ranging from a few inches to a few feet across. These lenses tend to be concentrated in channel scours, either at the base of the upper unit or within the upper unit (Fig. 9). The irregular clay masses probably represent overbank deposits that were undercut and caved by floodwaters.

The Hall Irwin Windsor pit is approximately 14.3 miles downstream from the Taft Hill pit. Two stratigraphic units are easily observed (Fig. 10). The upper unit is about 3 feet thick, and is overlain by clay overbank deposits and 


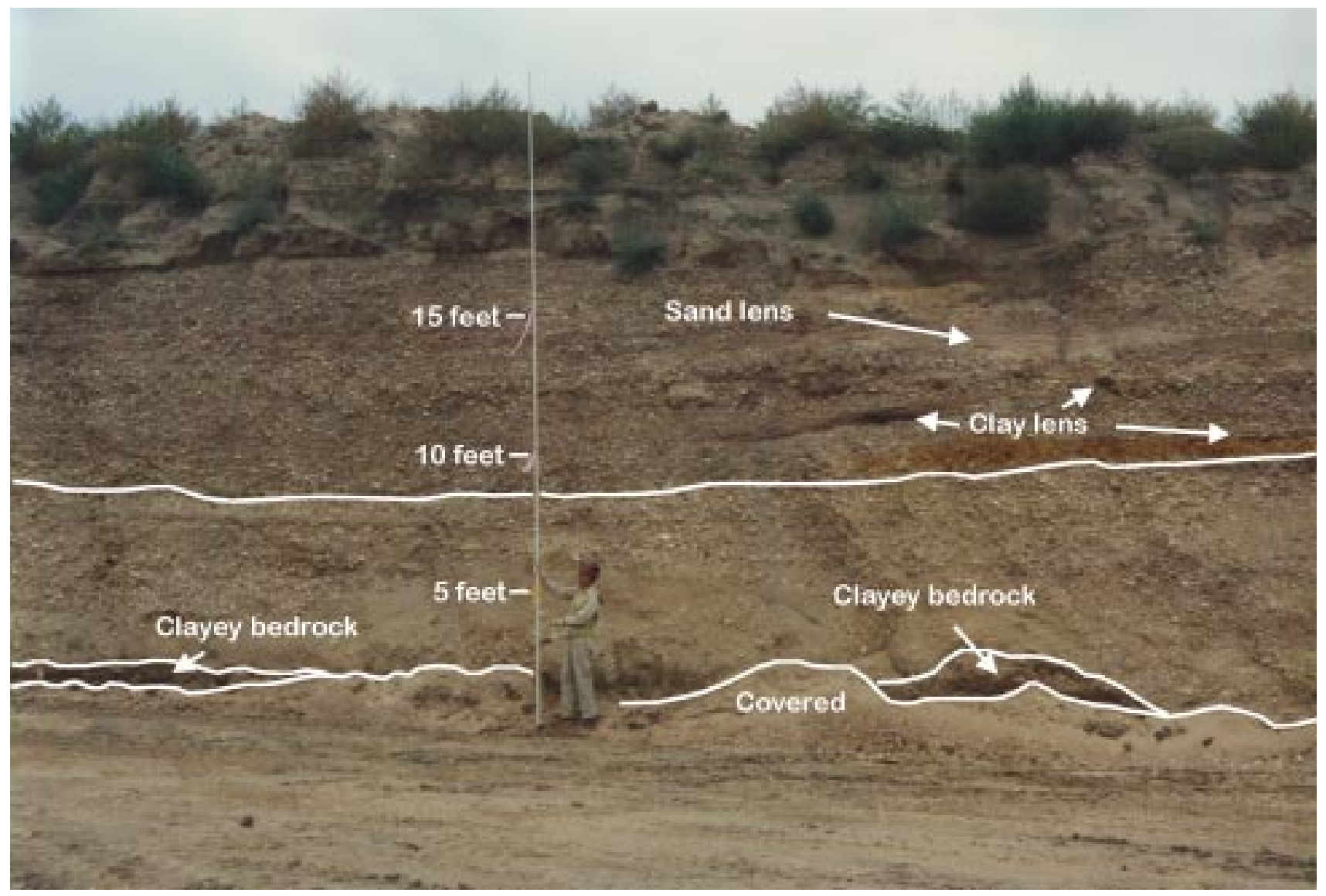

Figure 11.- Photograph showing changes in texture and color between the upper and lower stratigraphic units at the Western Mobile (LaFarge) $35^{\text {th }}$ Street pit near Greeley, Colorado.

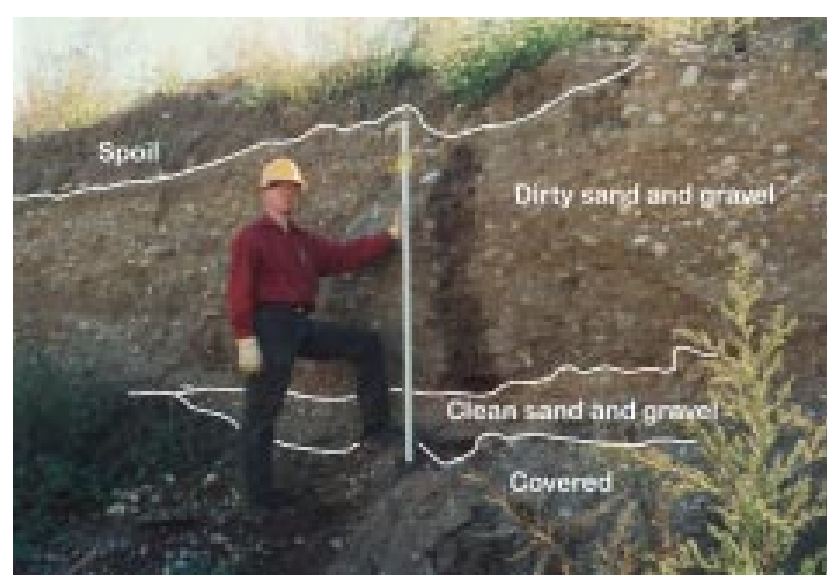

Figure 12.-Photograph showing dirty gravel at Western Mobile (LaFarge) Timnath pit near Fort Collins, Colorado.

soil. The unit consists of sand and gravel, is dark grayish brown and brown, and is classified as 10YR 4/2 and 10YR 5/3 on the Munsell soil color chart (Anonymous, 1994). The contact with the lower unit is an irregular erosional surface overlain by clay lenses. The lower unit is coarser than the upper unit and consists of imbricate cobble gravel that dips to the south. The lower unit contains sand lenses up to two feet thick. The color is grayish brown to dark grayish brown (10YR $5 / 2$ to $10 \mathrm{YR}$ $4 / 2$ on the Munsell soil color chart).

Two stratigraphic units are also readily distinguishable at the Western Mobile (LaFarge) $35^{\text {th }}$ Street pit (Fig. 11), approximately 24.4 miles downstream from the Taft Hill pit. In the $35^{\text {th }}$ Street pit, distinct differences in structure, grain size distribution, and color can be observed between the two units. The upper unit is about 15 feet thick, and consists of interlayered pebble gravel with clay lenses and pebbly sand lenses. The color is light gray to light brownish gray (10YR 7/2 to $10 \mathrm{YR} 6 / 2$ on the Munsell soil color chart). The lower unit is about 8 feet thick. The top seven feet of the unit consists of cobble to pebble gravel, is poorly stratified, and is pale brown to brown (10YR 6/3 to 10YR6/4 on the Munsell soil color chart). The bottom foot of the unit is clean sand. The sand rests on clayey bedrock. The entire deposit thickens to the south.

A third, very localized stratigraphic unit, described as "dirty gravel" (Schneider and Hershey, 1961), was encountered in a number of test holes (Fig. 3, sections AA' and B-B'). At the Western Mobile (LaFarge) Timnath pit (Fig. 12) approximately four feet of very indurated 
cobble/pebble gravel with a silt matrix (dirty gravel) overlies clean sand and pebble gravel. The color is very dark grayish brown (10YR 3/2 on the Munsell soil color chart). The dirty gravel was observed on the floodplain of the Cache la Poudre River at the Timnath pit, but from drill hole data, appears to occur within the Broadway Alluvium. The unit may be a debris flow that originated on the valley side and slid onto the floodplain.

\section{Sampling Plan}

Gravel deposits beneath the floodplain and low terraces of the Cache la Poudre River valley were sampled to measure downstream and stratigraphic variation in particle size and other characteristics that might be indicative of aggregate quality. Although the primary target of sampling was downstream variation, field observations revealed local stratigraphic units in the gravel that presented the possibility of subtle vertical variation.

A multilevel sample design was used to measure variation in the gravel deposits (Fig. 2). Strategies for sampling gravel have been discussed by Lindsey and Langer $(1998,1999)$. Eight sites were selected at gravel pits from Fort Collins to Greeley, representing about 25 miles of the Cache la Poudre valley (Fig. 2). Although sites are more or less evenly spaced about 4-5 miles apart, distance between sites ranges from 1-3 miles for a cluster of 3 sites to 7 miles for the sites located at the upstream end. At all sites except the Western Mobile (LaFarge) $35^{\text {th }}$ Street pit near Greeley, two or three vertical sections through the entire thickness of gravel were selected approximately 500 feet apart and then sampled. At three sites, replicate samples of sections were collected and sieved to estimate sample error for particle size.

The use of a sample design allows partition of the natural variation in the character of the gravel. The model described above targets estimation of downstream variation and compares this variation to other sources of variation, such as local variation or sampling error, that may obscure downstream trends. The equation for the variance model is:

$$
\mathrm{S}_{\mathrm{T}}^{2}=\mathrm{s}_{\alpha}^{2}+\mathrm{s}_{\beta}^{2}+\mathrm{s}_{\mathrm{e}}^{2}
$$

Where $\mathrm{S}_{\mathrm{T}}^{2}=$ total variance, $\mathrm{s}_{\alpha}^{2}=$ variance among sites (downstream variation), $\mathrm{s}_{\beta}^{2}=$ variance among sections (local variation), and is $\mathrm{s}^{2}=$ sample (error variance). In addition to the above-described sampling plan, individual gravel units at all sections and sites except the Taft Hill pit were sampled to test for differences between the upper and lower units. As described under General Stratigraphy, the upper and lower gravel units at each locality exhibit subtle differences in color and sorting. Although the two units are not consistent in appearance throughout the Cache la Poudre River valley, they were sampled separately to verify that observation.

\section{Sample Processing}

Vertical trench samples (Krumbein and Pettijohn, 1938) were collected by using a shovel or hoe to scrape gravel from a vertical indentation cut in a clean pit face. All of the gravel that falls is caught in a bucket. Samples ranged from 36 to 203 pounds, with an average weight of 69 pounds. In general, the sample size was largest for the coarsest gravel, as recommended by Wentworth (1926).

Samples were sieved into size fractions greater than $3 / 16,3 / 8,3 / 4,1.5$, and 3 inches; the proportion of particles greater than 6 inches, present at one site, was estimated in the field. All material that passes through the 3/16-inch sieve is classified as fines. Particle size was measured in inches and fractions of inches; however, it is convenient to convert measurements into millimeters for calculating some size parameters, such as median and quartile sizes. Accordingly, both English and metric units are used to express particle size.

The 3/4 to 1.5 -inch pebble fraction of each sample was reserved for determination of rock type, shape, and roundness. Fifty pebbles from each sample were selected by cone-and-quarter splitting. A total of 1,450 pebbles from all eight sample sites were examined. In addition to rock identification, each pebble was classified by physical and chemical aggregate quality (Langer and Knepper, 1998). Shape was determined by measuring the long (A), intermediate (B), and short (C) dimensions with a ruler. The tendency for equidimensional shape, termed sphericity, was calculated from three axes (Krumbein, 1941). Roundness was estimated by visual comparison with standards. Study methods, statistical analysis, and interpretation of particle size, shape, and roundness are described by Pettijohn (1975) and additional details on methods of measuring and statistical analysis are provided by Krumbein and Pettijohn (1938). Sample data are summarized in Appendix Tables A1-A5; downstream distances used for plotting data are given in Table A6.

\section{Particle Size}

The quantity of coarse gravel, expressed as average cumulative weight percent (pct) at each site, decreases downstream from Fort Collins to Greeley (Fig. 13). Above Fort Collins, about 50 pct of gravel collects on the 1.5 -inch sieve, whereas barely 30 pct collects on the same sieve size at Greeley. Likewise, three-quarter inch gravel ranges from 60 pct above Fort Collins to about 50 pct at Greeley. For gravel finer than 3/4 inch, the downstream decline is barely noticeable. Most variation in the quantity of fine gravel is local. Linear regression lines were fitted to site averages to enable prediction of downstream trends, but considerable local variation is evident.

The variation (expressed as variance) of particle size at each level of the sample design was estimated to assess downstream versus local effects (Table 1; computational methods of Krumbein and Graybill, 1965). The percent of total variance between sites (representing downstream variation) increases with increasing particle size, from 

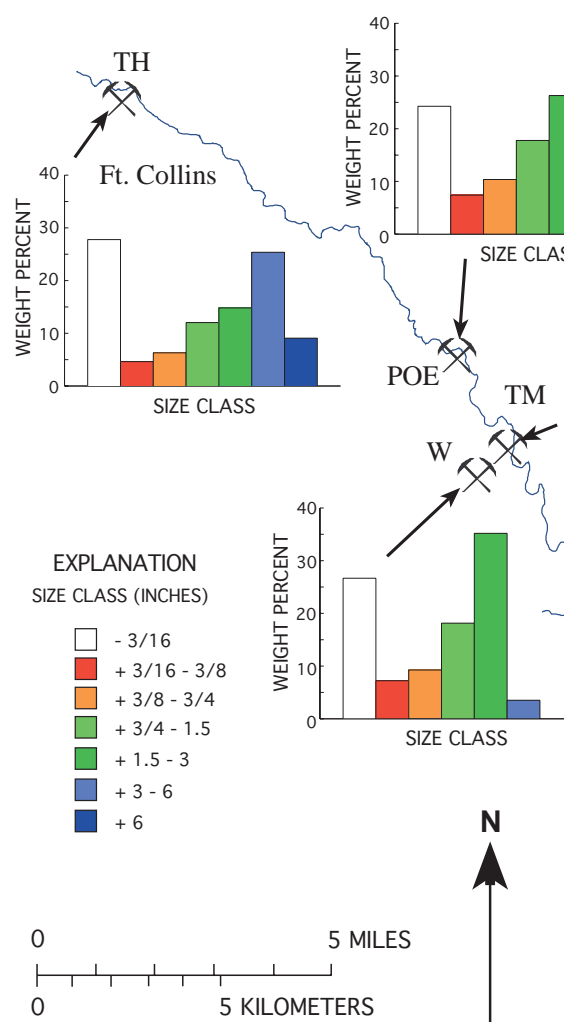
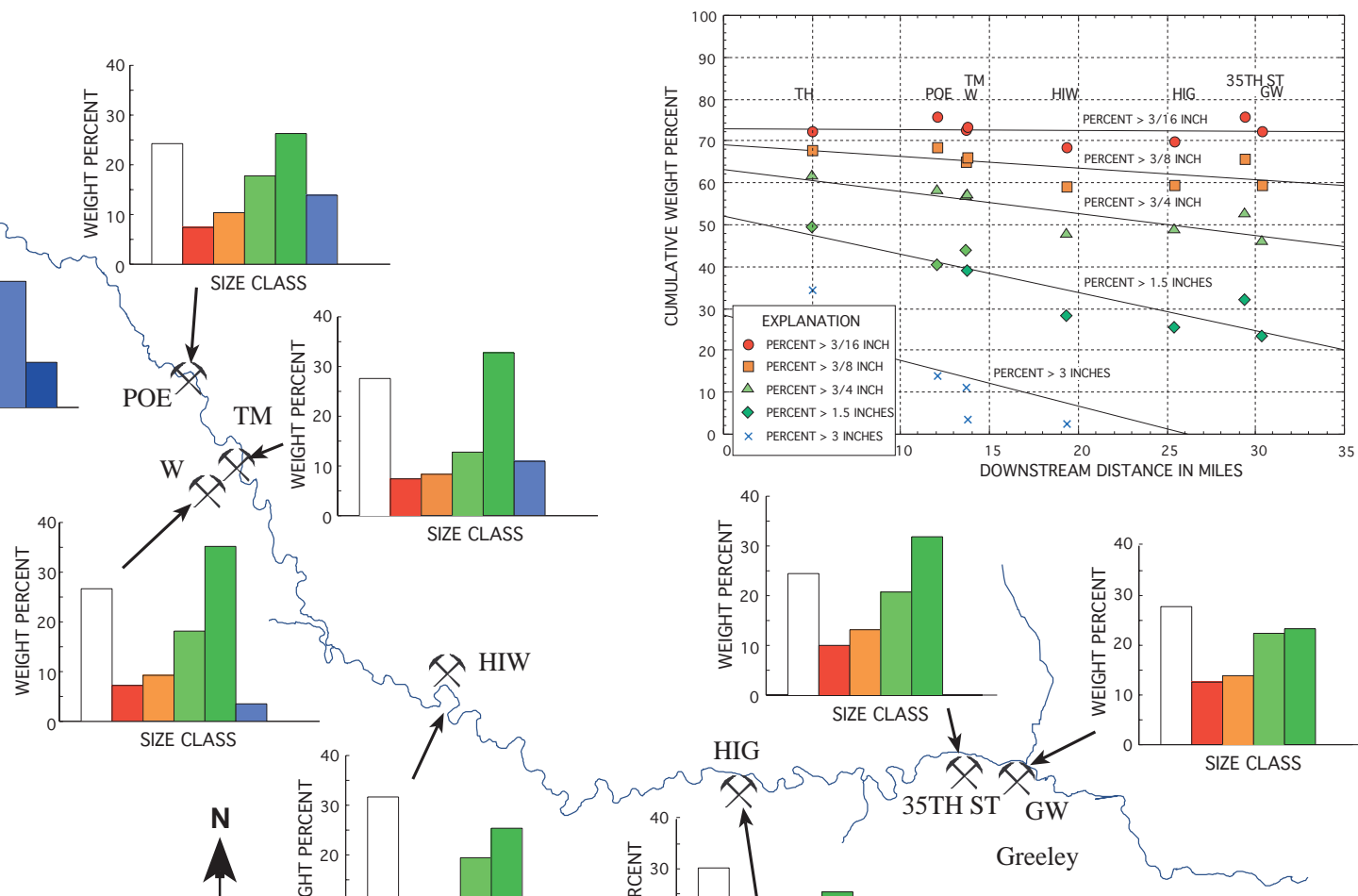

Figure 13.-Downstream variation in particle size, Cache la Poudre River valley gravel. Histograms and graph show average values at each site. Abbreviations for sites at gravel pits: TH, LaFarge Taft Hill; POE, LaFarge Port-ofEntry; TM, LaFarge Timnath; W, LaFarge Weitzel; HIW, Hall Irwin Windsor; HIG, Hall Irwin Greeley; 35TH ST, LaFarge 35th Street Greeley; and GW, LaFarge Greeley West (25 ${ }^{\text {th }}$ Street).

Table 1.--Variance components for gravel particle size parameters, Cache la Poudre River valley from Fort Collins to Greeley, Colorado. PERCENT>, cumulative weight percent for stated particle size; Q1, first quartile (25th percentile); Q3, third quartile (75th percentile); MM, millimeters. Average sample weight, $70 \mathrm{lbs}$; range, 36-203 lbs. *, F-test for differences among means significant at 0.05 level.

\begin{tabular}{lcccc}
\hline SIZE PARAMETER & $\begin{array}{c}\text { TOTAL } \\
\text { VARIANCE }\end{array}$ & $\begin{array}{c}\text { BETWEEN } \\
\text { SITES }(8)^{1}\end{array}$ & $\begin{array}{c}\text { BETWEEN } \\
\text { SECTIONS } \\
(1-3 / \text { SITE) }\end{array}$ & $\begin{array}{c}\text { BETWEEN } \\
\text { SAMPLES }^{3} \\
(1-2 / \text { SECTION })\end{array}$ \\
\hline PERCENT > 3/16 INCH & 24 & 0 & 38 & 62 \\
PERCENT > 3/8 INCH & 35 & 17 & 4 & 79 \\
PERCENT > 3/4 INCH & 49 & $43^{*}$ & 0 & 57 \\
PERCENT > 1.5 INCHES & 91 & $67^{*}$ & 0 & 33 \\
PERCENT > 3 INCHES & 121 & $77^{*}$ & 0 & 23 \\
Q1 (MM) & 4 & 0 & 0 & 100 \\
MEDIAN (MM) & 60 & $58^{*}$ & 2 & 40 \\
Q3 (MM) & 307 & $68^{*}$ & 0 & 32 \\
ESTIMATED & & & & \\
MAXIMUM SIZE (MM) & 1215 & $67^{*}$ & 0 & 33 \\
\hline
\end{tabular}

${ }^{1}$ Downstream variation

${ }^{2}$ Local variation

${ }^{3}$ Sample error 
zero for the cumulative weight percent of particles $>3 / 16$ inch, to $77 \mathrm{pct}$ for the cumulative weight percent of particles $>3$ inches. Analysis of variance (F-tests) shows that the sample design was sufficient to distinguish cumulative weight percent of particle sizes $>3 / 4$ inch among sites. Thus, downstream trends for coarse sizes (Fig. 13) are considered stable; trends for cumulative weight percent of particle sizes of $>3 / 8$ and $>3 / 16$ inch are not predictable, mainly because the cumulative values for these sizes do not vary appreciably downstream. For small particle size, downstream variation is too small relative to sample error to measure with confidence.

Potential stratigraphic (vertical) variation in gravel coarseness was tested by comparing samples taken from the upper unit of the gravel with those taken from the lower unit (Fig. 14). At some places, the upper and lower units of the gravel could be distinguished by subtle differences in color, size, or sorting, but the available data suggests only minor stratigraphic effect on particle size. For particle size, the large magnitude of sampling error (Table 1) severely limits comparisons based on unreplicated samples from the upper and lower units of the gravel. If the upper and lower units of the gravel at near one. For cumulative weight percent of particles $>3$ inches, the ratio is less than one, suggesting concentration of the coarsest gravel in the lower unit. For ratios of other particle sizes, considerable scatter is evident (Fig. 14). Ratios are not consistent among adjacent sites, possibly indicating lateral variation in particle size within each stratigraphic unit. However, much of the variation in ratios may also be interpreted as random because sample error is large.

\section{Lithology and Gravel Quality}

Aggregate quality is related in part to gravel lithology; hence the two are discussed together. Potential sources of aggregate are defined according to general

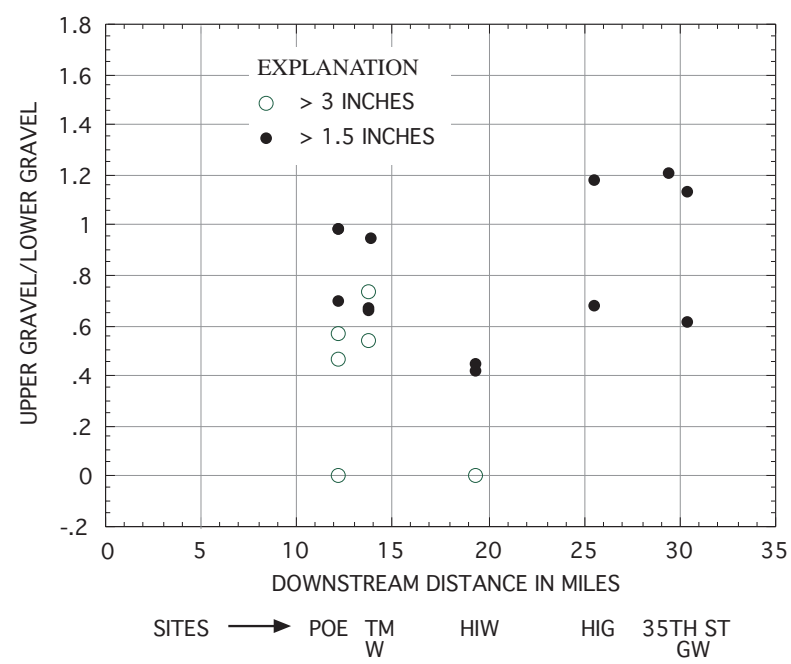
each site have the same particle size, their ratios should be

physical and chemical quality. Physical quality is defined as satisfactory, fair, or poor, and relates to lithology and weathering. Satisfactory aggregate has physical properties that make it suitable for most purposes. Satisfactory aggregate contains clasts that generally are strong, hard, relatively free from fractures, and not chiplike; capillary absorption is very small or absent; and the surface texture is relatively rough. Fair aggregate has physical properties that make it useful for many purposes, but commonly can not be used where engineering specifications are strict such as in concrete or asphalt. Clasts are generally friable, moderately fractured, and flat or chiplike; capillary absorption is small to moderate; and fracture surfaces are relatively smooth and impermeable. Poor aggregate has physical properties that greatly limit its use. Clasts are generally weak, highly fractured, and friable; capillary absorption is moderate to high; and fracture surfaces are relatively smooth and impermeable. In many circumstances, potential sources of crushed stone can be processed to improve quality to meet special requirements.

Chemical quality is defined as either innocuous or deleterious, and is related to mineralogy and presence of other deleterious material. Innocuous aggregate contains no constituents that dissolve or react chemically to a significant extent in the atmosphere, water, or hydrating portland cement in concrete or mortar under ordinary conditions. Deleterious aggregate contains a significant proportion of constituents that are known to react chemically under conditions ordinarily prevailing in portland cement concrete or mortar. The reaction may produce significant volume change, interfere with the normal course of hydration of portland cement, and produce other harmful effects on concrete. Deleterious material is commonly found in silicic volcanic rocks and ash beds, which may contain volcanic glass and unstable silica polymorphs.

Overall, the lithology of gravel pebbles in the Cache

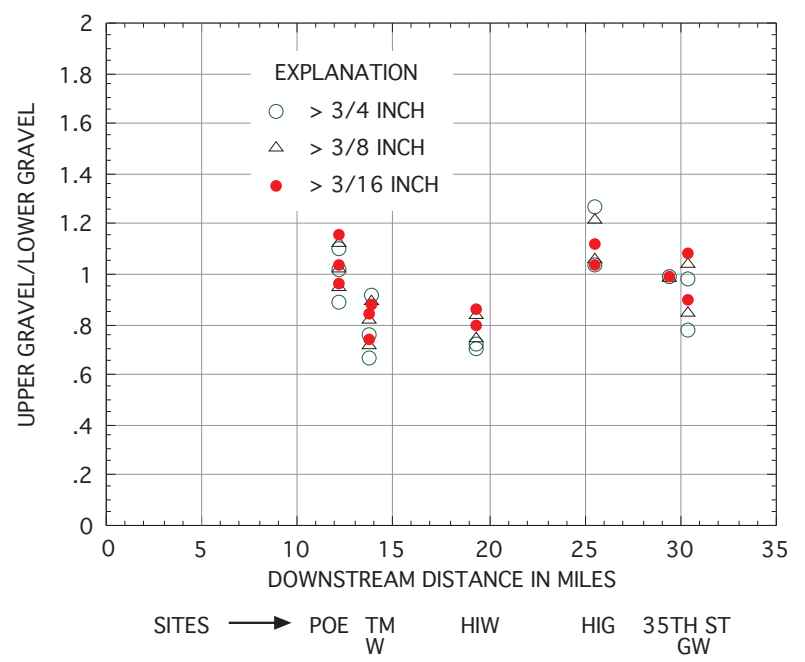

Figure 14.-Plot showing ratio of gravel sizes in upper versus lower gravel unit, Cache la Poudre River valley. Values for individual samples shown at each site. 
la Poudre valley is dominated by granite $(24.9 \mathrm{pct})$ and pegmatite (48.3 pct) (Fig. 15). Gneiss, quartz, and quartzite make up another 5-7 pct each. These rocks were derived from the upper part of the Cache la Poudre drainage basin in the Front Range. Among the minor rock types in the gravel, diabase and schist were also derived from the mountains. Volcanic porphyry and sandstone were derived from lithologic units exposed in the mountain-front hogbacks or on the plains. The sparseness of volcanic porphyries accounts for the relatively high average of 98.9 pct chemically innocuous pebbles in the gravel.

Variance among sites is low for most rock types, but quartz, quartzite, and the volcanic porphyries show significant variation among sites, as does chemical quality (Table 2). For most other rock types, except for gneiss and perhaps diabase, variance is concentrated among samples.

Among those lithologic characteristics showing significant variance among sites, only quartz and quartzite appear to vary downstream in a systematic fashion (Fig. 15). Quartz plus quartzite is a measure of the physical and chemical maturity of the gravel. A straight line fitted to average site values can approximate the downstream increase in quartz plus quartzite. As expected, the proportion of physically satisfactory gravel, which has a high degree of between-sample variation (Table 2), shows no systematic downstream trend (Fig. 16). The proportion of chemically innocuous gravel, which varies significantly among sites, does not follow a discernible downstream trend either, but is lowest in the vicinity of Greeley (Fig. 16), where volcanic porphyry is most abundant (Fig. 15). The abundance of porphyry may, like quartz plus quartzite, reflect the greater hardness and durability of porphyry relative to other rock types during transport. However, the abundance of porphyry does not appear to increase gradually downstream, like that of quartz plus quartzite, but is concentrated near Greeley. No point source of porphyry that could account for an abrupt appearance is known.

Potential stratigraphic variation in gravel lithology and quality is weak (Figs. 17 and 18). At a few stations, the ratio of quartz plus quartzite in the upper versus lower gravel units exceeds 2, suggesting local enrichment of these resistant rock types by weathering or reworking. In contrast, ratios for innocuous chemical quality are consistently near one, indicating that whatever reworking occurred was not sufficient to affect chemical quality. Gravel of satisfactory physical quality appears to be less

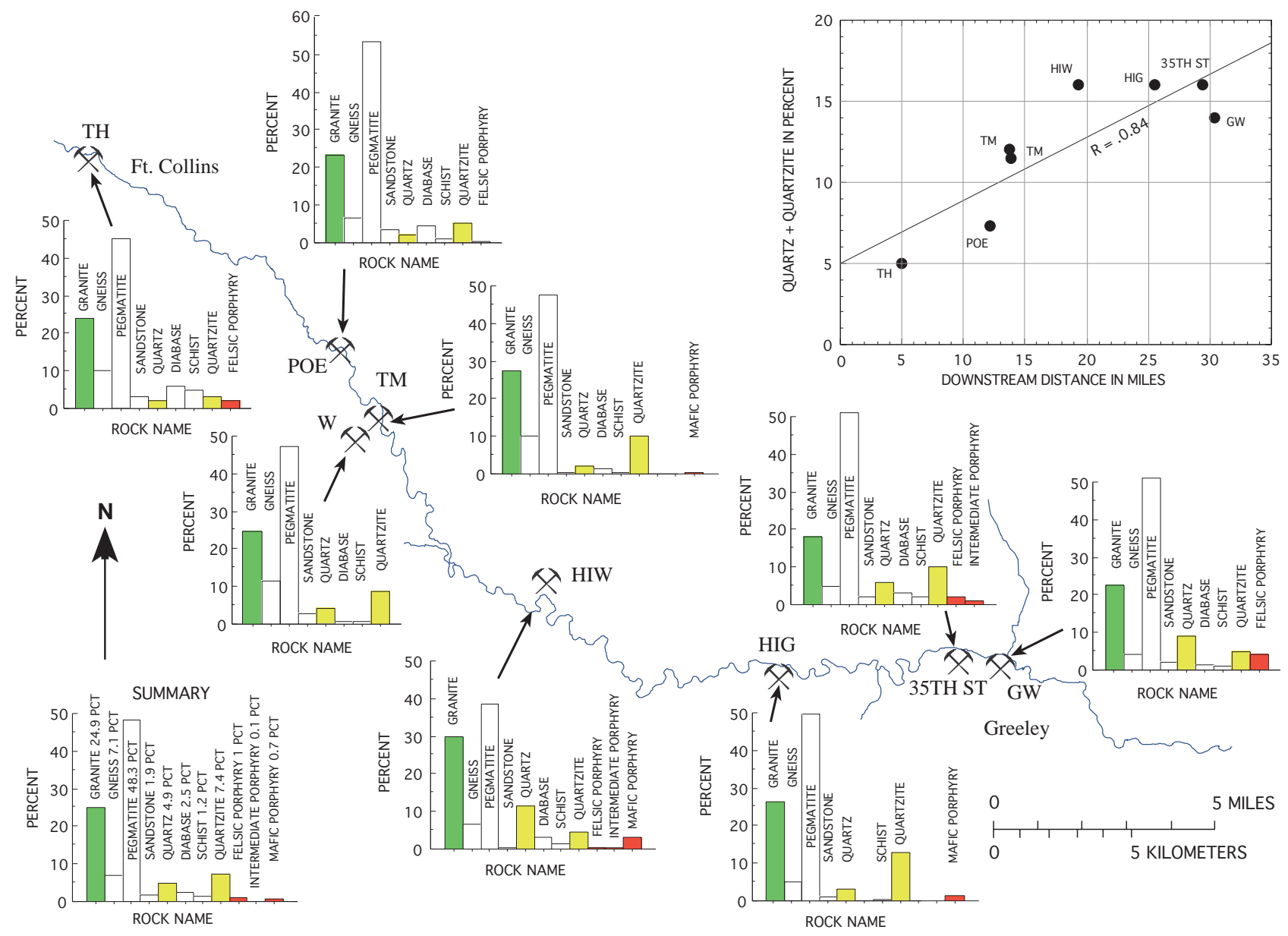

Figure 15.-Downstream variation in pebble lithology, Cache la Poudre River valley gravel. Histograms and graph show average values at each site. Abbreviations for sites are same as fig. 2. 
Table 2.--Variance components for gravel lithology and quality, Cache la Poudre River valley from Fort Collins to Greeley, Colorado. Rock type and quality determined for 50 pebbles per sample. *, F-test for differences among means significant at 0.05 level. PCT, percent.

\begin{tabular}{|c|c|c|c|c|}
\hline $\begin{array}{c}\text { ROCK TYPE OR } \\
\text { QUALITY (IN PCT) }\end{array}$ & $\begin{array}{c}\text { TOTAL } \\
\text { VARIANCE }\end{array}$ & $\begin{array}{l}\text { BETWEEN } \\
\text { SITES }(8)^{1}\end{array}$ & $\begin{array}{c}\text { BETWEEN } \\
\text { SECTIONS }^{2} \\
(1-3 / \text { SITE })\end{array}$ & $\begin{array}{c}\text { BETWEEN } \\
\text { SAMPLES }^{3} \\
(1-2 / \text { SECTION) }\end{array}$ \\
\hline & & \multicolumn{3}{|c|}{ Percent of Total Variance } \\
\hline GRANITE & 23 & 18 & 27 & 55 \\
\hline GNEISS & 18 & 0 & $71 *$ & 29 \\
\hline PEGMATITE & 81 & 9 & 0 & 91 \\
\hline SANDSTONE & 5.4 & 9 & 0 & 91 \\
\hline QUARTZ & 21 & $49 *$ & 0 & 51 \\
\hline DIABASE & 10 & 0 & 46 & 54 \\
\hline SCHIST & 3.0 & 22 & 13 & 65 \\
\hline QUARTZITE & 19 & $39 *$ & 0 & 61 \\
\hline FELSIC PORPHYRY & 3.0 & $54 *$ & 0 & 46 \\
\hline \multicolumn{5}{|l|}{ INTERMEDIATE } \\
\hline PORPHYRY & 0.3 & 17 & 0 & 83 \\
\hline MAFIC PORPHYRY & 3.2 & $18 *$ & 0 & 82 \\
\hline QUARTZ+QUARTZITE & 33 & $28 *$ & 0 & 72 \\
\hline TOTAL PORPHYRY & 6.3 & $23 *$ & 0 & 77 \\
\hline FAIR PHYSICAL & 81 & 36 & 5 & 59 \\
\hline $\begin{array}{l}\text { POOR PHYSICAL } \\
\text { SATISFACTORY }\end{array}$ & 32 & 17 & 7 & 76 \\
\hline PHYSICAL & 50 & 1 & 10 & 89 \\
\hline DELETERIOUS & & & & \\
\hline CHEMICAL & 3.0 & $62 *$ & 0 & 38 \\
\hline INNOCUOUS CHEMICAL & 3.0 & $62 *$ & 0 & 38 \\
\hline
\end{tabular}

${ }^{1}$ Downstream variation

${ }^{2}$ Local variation

${ }^{3}$ Stratigraphic variation (includes sampling error)
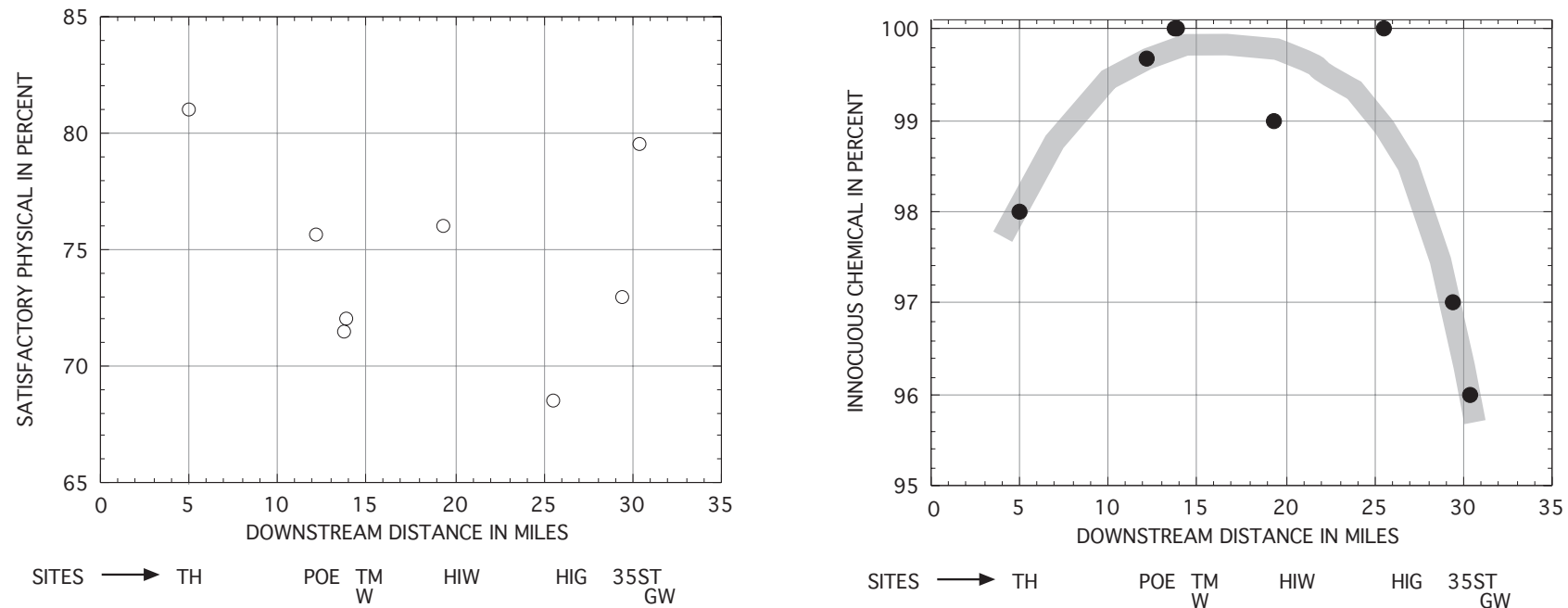

Figure 16.-Downstream variation in gravel quality, Cache la Poudre River valley. Average values for each site shown. Abbreviations for sites are same as fig. 2. 


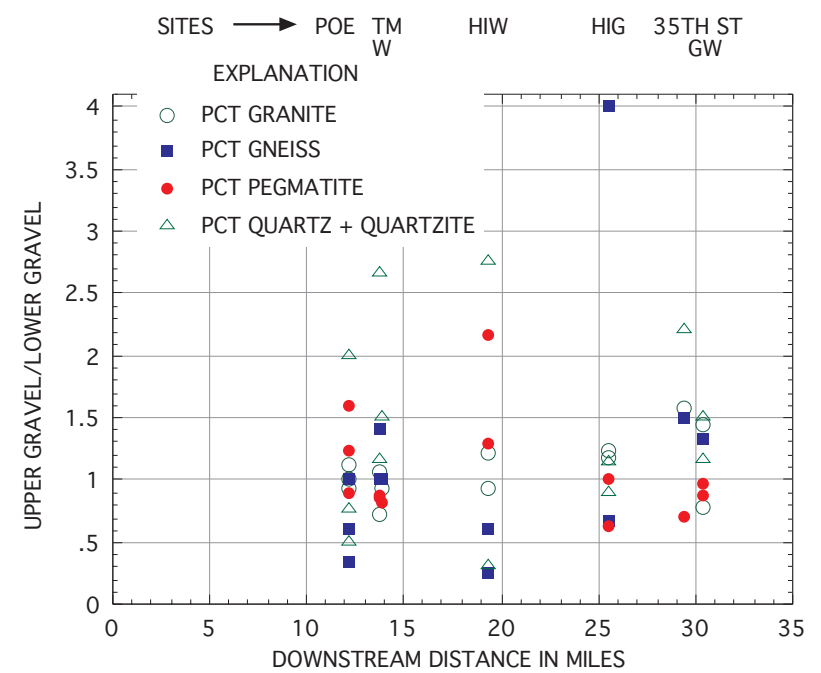

Figure 17.-Plot showing ratio of pebble lithology in upper versus lower gravel unit, Cache la Poudre River valley. Values for individual samples shown.

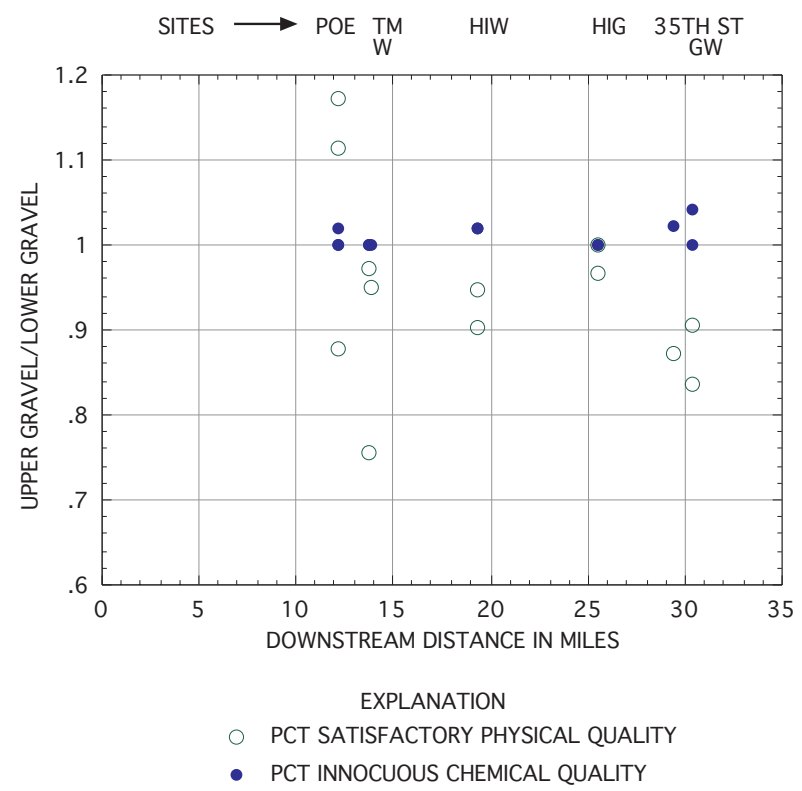

Figure 18.-Plot showing ratio of gravel quality in upper versus lower gravel unit, Cache la Poudre River valley. Values for individual samples shown.

abundant in the upper unit of the gravel than in the lower unit (ratios less than one, Fig. 18). Perhaps, the source of the upper unit has been weathered more than the lower unit.

\section{Pebble Shape}

Particle shape affects strength; flat and blade-shaped particles tend to be weak, whereas equidimensional particles tend to be strong (Langer and Knepper, 1998). Measurements of pebble shape in gravel of the Cache la Poudre River valley show a preponderance of strong particle shapes.

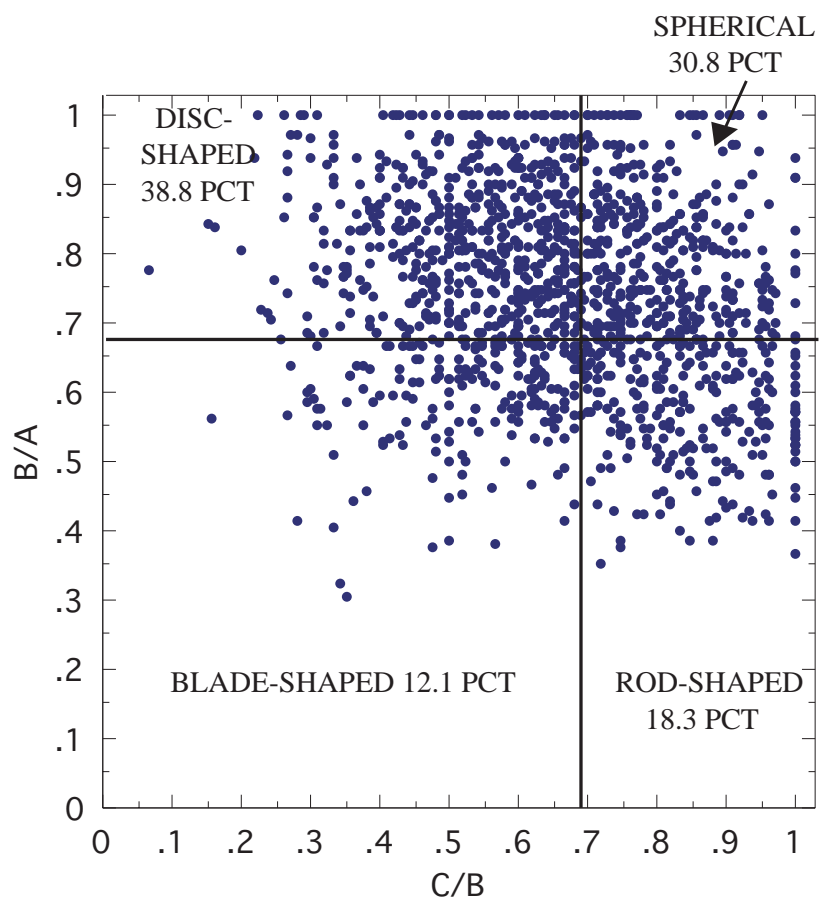

Figure 19.-Zingg diagram showing pebble shape, Cache la Poudre River valley gravel. Shape axes defined in Table 3.

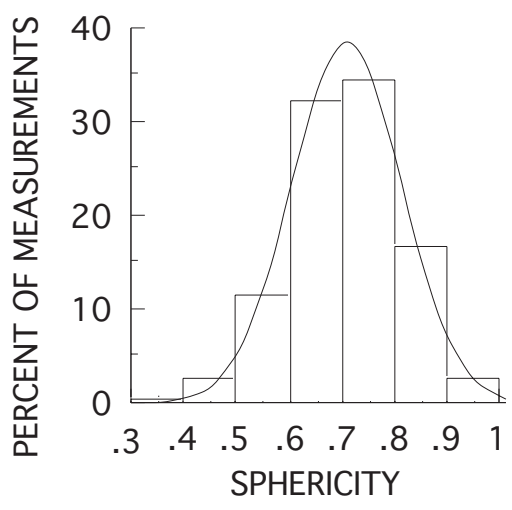

Figure 20.-Histogram showing calculated pebble sphericity, Cache la Poudre River valley gravel. Sphericity defined in caption, Table 3.

The shapes of pebbles in gravel of the Cache la Poudre River valley follow a pattern comparable but not identical to gravel of the South Platte River valley (Figs. 19 and 20) (Lindsey and others, 1998b). As classified on a Zingg diagram, pebbles are disc-shaped (38.8 pct versus 44.0 pct for the South Platte), spherical (30.8 pct versus $25.4 \mathrm{pct}$ for the South Platte), rod-shaped (18.3 pct versus $16.0 \mathrm{pct}$ for the South Platte) and blade-shaped (12.1 pct versus 14.6 pct for the South Platte). The shift toward spherical particles in the Cache la Poudre versus the South Platte may be due to the smaller proportion of layered gneiss in Poudre gravel than in South Platte 
Table 3.--Variance components for gravel pebble shape, Cache la Poudre River valley from Fort Collins to Greeley, Colorado. $\mathrm{A}=$ long axis; $\mathrm{B}=$ intermediate axis; $\mathrm{C}=$ short axis. MEAN SPHERICITY $(\Psi)={ }^{3} \sqrt{ }\left(\mathrm{BC} / \mathrm{A}^{2}\right)$, measures degree of equidimensional shape; when $\mathrm{A}=\mathrm{B}=\mathrm{C}, \Psi=1$. $\mathrm{PCT}$, percent of pebbles in 3/4-1.5 inch size fraction. Shape classified as spherical, disc-, rod-, and blade-shaped by criteria of Zingg (Pettijohn, 1975, fig. 3-18), 50 pebbles per sample. *, F-test for differences among means significant at 0.05 level. PCT, percent.

\begin{tabular}{lcccc}
\hline SHAPE PARAMETER & $\begin{array}{c}\text { TOTAL } \\
\text { VARIANCE }\end{array}$ & $\begin{array}{c}\text { BETWEEN } \\
\text { SITES }(8)^{1}\end{array}$ & $\begin{array}{c}\text { BETWEEN } \\
\text { SECTIONS }^{2} \\
(1-3 / \text { SITE })\end{array}$ & $\begin{array}{c}\text { BETWEEN } \\
\text { SAMPLES }^{3} \\
(1-2 / \text { SECTION })^{2}\end{array}$ \\
\hline MEAN B/A & & \multicolumn{3}{c}{ Percent } \\
MEAN C/B & 0.00058 & 0 & $51 *$ & 49 \\
MEAN SPHERICITY $(\Psi)$ & 0.00063 & 6 & 33 & 61 \\
PCT SPHERICAL & 0.00038 & 0 & $53 *$ & 47 \\
PCT DISC-SHAPED & 49 & 0 & $53 *$ & 47 \\
PCT ROD-SHAPED & 57 & 9 & 6 & 85 \\
PCT BLADE-SHAPED & 30 & 0 & 40 & 60 \\
\hline
\end{tabular}

${ }^{1}$ Downstream variation

${ }^{2}$ Local variation

${ }^{3}$ Stratigraphic variation (includes sampling error)

gravel. Pebbles having axial ratios of less than 0.5 , which might be structurally weak, are rare. Average calculated sphericity (0.707) is close to that of South Platte gravel (0.692).

Variance among sites is low for all shape parameters (Table 3). Most variation is local or among samples. No statistically significant downstream trend in shape can be detected in the available data.

Potential stratigraphic variation in pebble shape was examined, but ratios comparing the upper and lower units of the gravel were found to vary widely. The overall average of ratios is near one, suggesting no general stratigraphic control of shape (Fig. 21).

\section{Pebble Roundness}

Roundness refers to the degree to which particles lack angular corners; roundness may affect the behavior of aggregate particles in some applications, such as the tendency to shift under load in loose aggregate or asphalt.

Gravel in the Cache la Poudre valley tends to be rounded to well-rounded (Fig. 22). Angular pebbles are few. For the proportion of rounded and well-rounded pebbles, as well as average roundness, variance among sites is significant (Table 4). Average roundness values decline to a point 5-10 miles above Greeley but rise abruptly at Greeley (Fig. 22). The reason for this high, and unpredictable, variation among sites downstream is not known. In the streambed of the South Platte, pebble roundness was observed to decrease downstream (Lindsey and Shary, 1997).

Stratigraphic variation in pebble roundness is suggested by high ratios for angular, subangular, and subrounded particles in the upper unit versus the lower unit of gravel at some sites (Fig. 23). Sparse angular
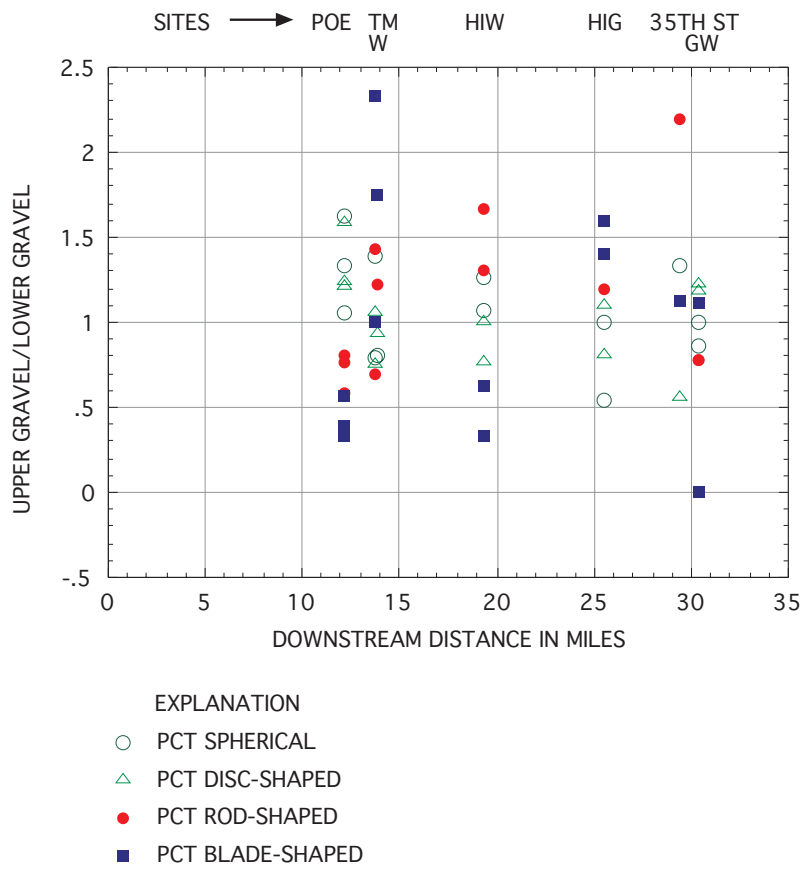

Figure 21.-Plot showing ratio of pebble shape in upper versus lower gravel unit, Cache la Poudre River valley. Values for individual samples shown.

pebbles tend to be more abundant in the upper unit of the gravel. Freezing and thawing during weathering of the source gravel, or breakage during stream transport, might account for the greater abundance of angular pebbles in the upper unit.

\section{CONCLUSIONS}

Four different gravel deposit models are defined for the Cache la Poudre River valley. From the highest 

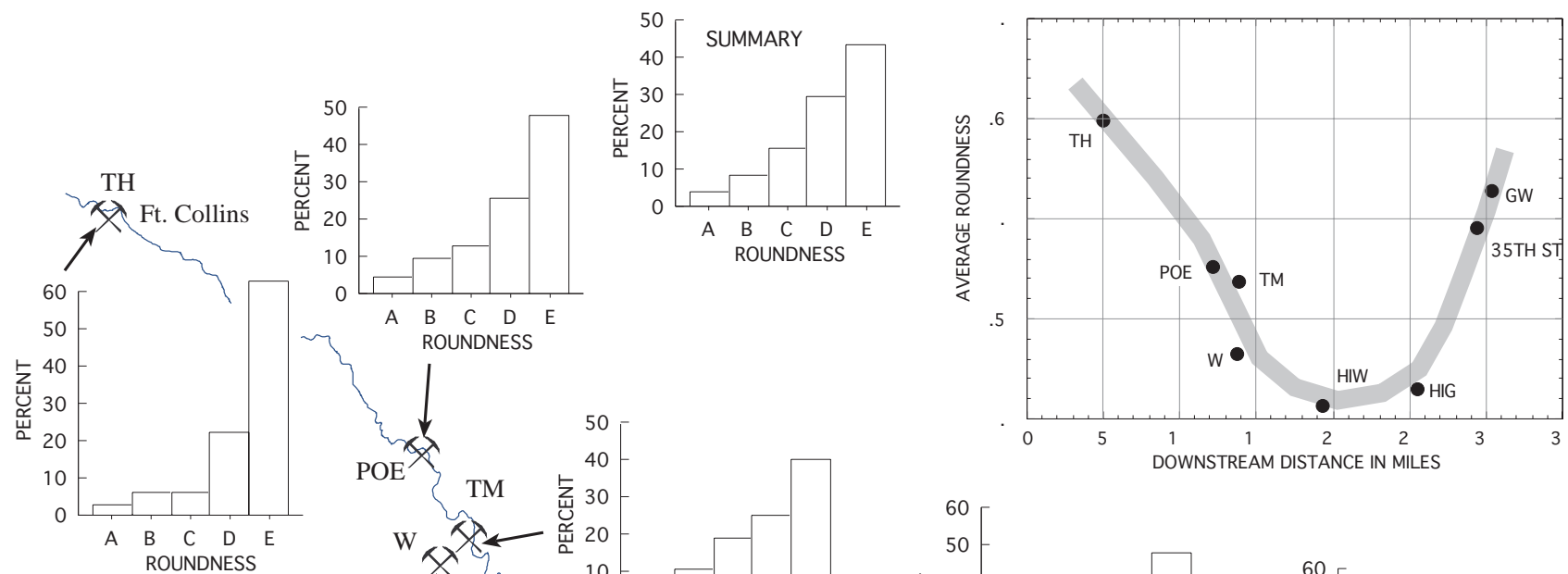

$\begin{aligned} & 50 \\ & 40 \\ & 30\end{aligned}-$
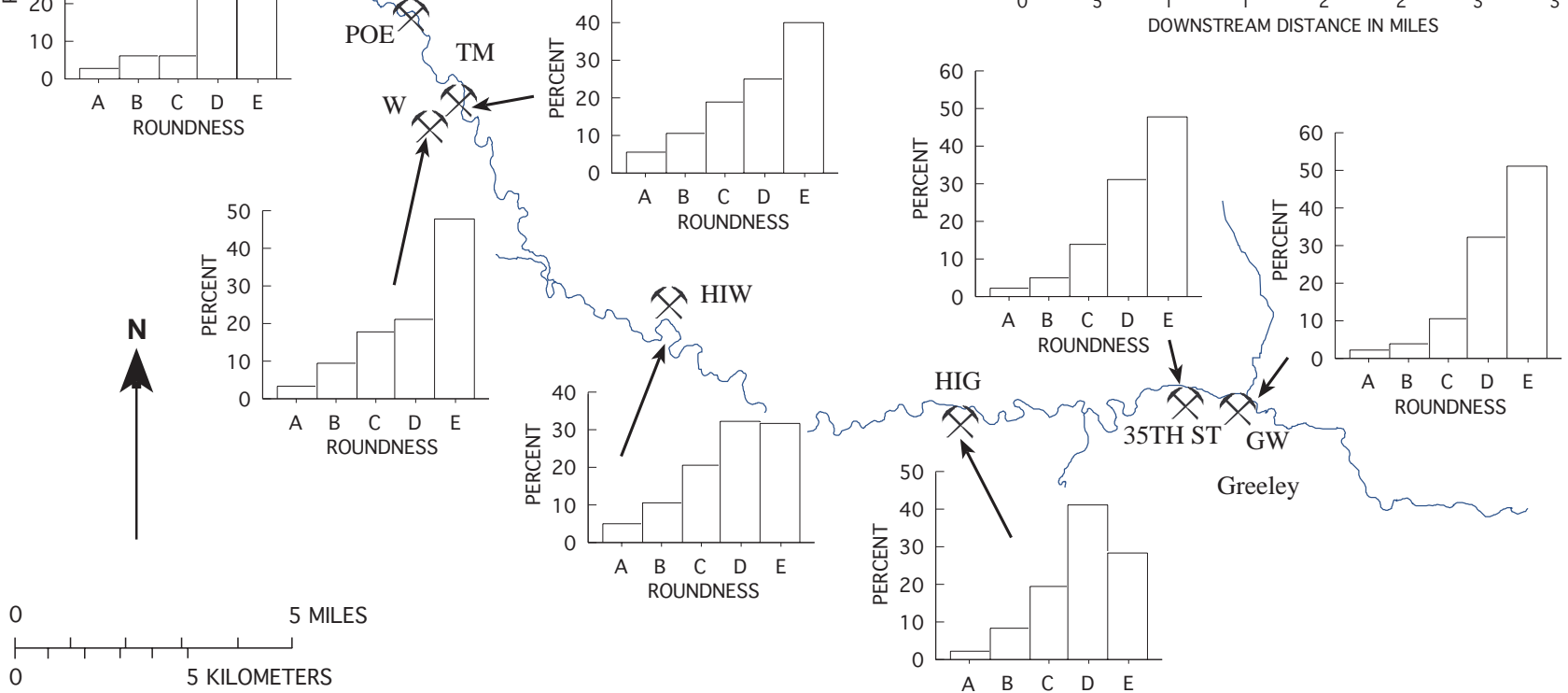

Greeley

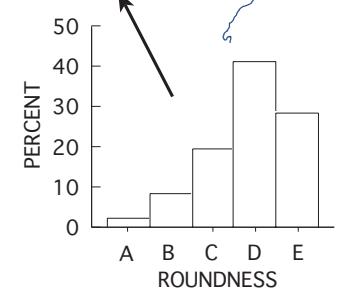

Figure 22.-Downstream variation in pebble roundness, Cache la Poudre River valley gravel.

Histograms and graph show average values at each site. Roundness classes are:A, angular; B, subangular; C, subrounded; D, rounded; and E, well-rounded. Average roundness (defined in Table 4) at each site shown in upper right.

Table 4.--Variance components for gravel pebble roundness, Cache la Poudre River valley from Fort Collins to Greeley, Colorado. PCT, percent of pebbles in 3/4-1.5 inch size fraction; roundness estimated by visual comparison with roundness classes (Pettijohn, 1975, fig. 3-24), 50 pebbles per sample. AVERAGE ROUNDNESS $=(($ PCT A x .125 $)+($ PCT B x .2) + $($ PCT C x .315) + (PCT D x .5) + (PCT E x .8) $) / 100 . *$, F-test for differences among means significant at 0.05 level. PCT, percent.

\begin{tabular}{lcccc}
\hline ROUNDNESS & $\begin{array}{c}\text { TOTAL } \\
\text { VARIANCE }\end{array}$ & $\begin{array}{c}\text { BETWEEN } \\
\text { SITES }(8)^{1}\end{array}$ & $\begin{array}{c}\text { BETWEEN } \\
\text { SECTIONS } \\
(1-3 / \text { SITE })\end{array}$ & $\begin{array}{c}\text { BETWEEN } \\
\text { SAMPLES } \\
(1-2 / \text { SECTION })\end{array}$ \\
\hline PCT A (ANGULAR) & 7 & \multicolumn{3}{c}{ Percent of Total Variance } \\
PCT B (SUBANGULAR) & 21 & 0 & 0 & 95 \\
PCT C (SUBROUNDED) & 50 & 23 & 11 & 89 \\
PCT D (ROUNDED) & 75 & $37^{*}$ & 0 & 77 \\
PCT E (WELL-ROUNDED) & 160 & $51^{*}$ & 0 & 63 \\
AVERAGE ROUNDNESS & 0.0036 & $40^{*}$ & 0 & 49 \\
\hline
\end{tabular}

${ }^{1}$ Downstream variation

${ }^{2}$ Local variation

${ }^{3}$ Stratigraphic variation (includes sampling error) 


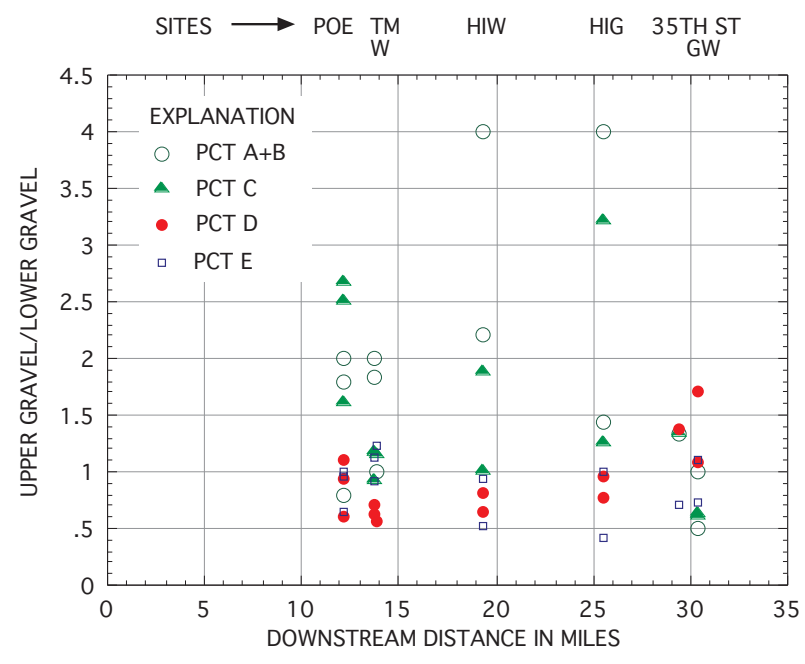

Figure 12.-Plot showing ratio of pebble roundness in upper versus lower gravel unit, Cache la Poudre River valley. Values for individual samples shown.

(oldest) to lowest (youngest) the models are 1) dissected terraces, 2) alluvial fans, 3) high terraces, and 4) floodplains and low terraces. The floodplain and low terraces are underlain by coarse gravel, which currently is the most exploited aggregate resource in the Cache la Poudre River valley.

From top to bottom, the floodplain and low terraces are underlain by 1) 3-5 feet of soil and overbank deposits and 2) two well-sorted, stratified, gravel deposits. A third stratigraphic unit, described as "dirty gravel," locally occurs in the study area; it consists of very indurated cobble/pebble gravel with a silt matrix.

Gravels of the Cache la Poudre River valley are coarsest upstream. Downstream decrease in the proportion of coarse gravel can be estimated by statistical sampling and analysis, but the proportion of fine gravel and sand is too variable to estimate with confidence. With only a few exceptions, downstream changes in other characteristics such as lithology and shape cannot be predicted with confidence. One exception is the content of quartz plus quartzite, a measure of physical and chemical maturity, which increases downstream. Pebble roundness decreases downstream but rises abruptly at Greeley. The proportion of physically satisfactory gravel, which is high at all sites, is too variable to predict downstream. The proportion of chemically innocuous gravel, everywhere measured at $96 \mathrm{pct}$ or greater, appears to be highest in the middle reaches of the Cache la Poudre River valley.

The lower gravel unit contains the highest proportion of coarse ( $>3$ inch) particles. The upper gravel unit tends to contain more quartz plus quartzite, has poorer physical quality, and contains a higher proportion of angular pebbles than the lower gravel. Although weakly defined, these stratigraphic differences are consistent at most sites. Weathering, followed by transport in the river, might be expected to concentrate quartz and quartzite, degrade physical quality, and break pebbles into angular fragments. This conclusion is consistent with the appearance at most sites of a sharp, erosional contact between the upper gravel unit and the lower gravel. The erosional contact between gravel units, together with evidence of degradation by weathering and transport prior to deposition of the upper gravel, indicates that the upper gravel was derived mainly by reworking of the older, lower gravel.

\section{REFERENCES CITED}

Anonymous, 1994, Munsell soil color charts: New Windsor, New York, Macbeth Division of Kollmorgen Instruments Corporation.

Bliss, J.D., 1993, Modeling sand and gravel deposits-initial strategy and preliminary examples: U. S. Geological Survey Open-File Report 93-200, 31 p.

Colton, R.B., 1978, Geological map of the Boulder-Fort Collins-Greeley area, Front Range Urban Corridor, Colorado: U. S. Geological Survey Miscellaneous Investigations Map I-855-G, scale 1:100,000.

Colton, R.B., and Fitch, H.R., 1974, Map showing potential sources of gravel and crushed-rock aggregate in the Boulder-Fort Collins-Greeley Area, Front Range Urban Corridor, Colorado: U.S. Geological Survey Miscellaneous Investigations Map I-856-A, scale $1: 100,000$.

Cox, D.P., Barton, P.B., and Singer, D.A., 1986, Mineral deposit models, Introduction, in: Cox, D.P., and Singer, D.A., eds., Mineral deposit models: U. S. Geological Survey Bulletin 1693, p. 1-10.

Jiongxin, Xu, 1996, Underlying gravel layers in a large sand bed river and their influence on downstream-dam channel adjustment: Geomorphology, v. 17, n. 4, p. 351-360.

Kondolf, G.M., 1998, Environmental effects of aggregate extraction from river channels and floodplains, in Bobrowsky, P. T., ed., Aggregate resources - A global perspective: Rotterdam, Netherlands, Balkema, p. 113130.

Krumbein, W. C., 1941, Measurement and geological significance of shape and roundness of sedimentary particles: Journal of Sedimentary Petrology, v. 11, no. 2, p. 64-72.

Krumbein, W. C., and Graybill, F. A., 1965, An introduction to statistical models in geology: New York, McGraw-Hill, 475 p.

Krumbein, W. C., and Pettijohn, F. J., 1938, Manual of sedimentary petrography: New York, AppletonCentury-Crofts, 549 p.

Langer, W.H., Arbogast, B.F., Knepper, D.H. Jr., Lindsey, D.A., Nealey, L.D., and Roelle J.E., 1997, U.S. Geological Survey Front Range Infrastructure Resources Project: Proceedings, $5^{\text {th }}$ Annual Symposium, International Center for Aggregates Research, University of Austin, Texas, p. E-2-1-1 - E2-1-8. 
Langer, W. H., and Knepper, D. H., Jr., 1998, Geologic characterization of natural aggregate: a field geologist's guide to natural aggregate resource assessment, in Bobrowsky, P. T., ed., Aggregate resources, a global perspective: Rotterdam, Balkema, p. 275-293.

Langer, W. H., Lindsey, D. A., Knepper, D. H., Jr., and Faber, B. G., 1999, A GIS decision-support-system demonstration of aggregate maps and data for the Front Range Infrastructure Resources Project Area, in Johnson, K. S., ed., Proceedings of the $34^{\text {th }}$ Forum on the geology of industrial minerals, 1998: Oklahoma Geological Survey Circular 102, p. 139-146.

Lindsey, D.A., 1997, An introduction to sand and gravel deposit models, Front Range Urban Corridor: U.S. Geological Survey Open File Report 97-81, 6 p.

Lindsey, D. A., and Langer, W. H., 1998, Slide show on gravel deposit models and measuring aggregate quality, Front Range Urban Corridor, Colorado: U.S. Geological Survey Open-File Report 98-322, 17 p.

Lindsey, D. A., and Langer, W. H., 1999, Defining models and measuring aggregate quality for gravel deposits of Front Range Urban Corridor, Colorado, in Johnson, K. S., ed., Proceedings of the $34^{\text {th }}$ Forum on the geology of industrial minerals, 1998: Oklahoma Geological Survey Circular 102, p. 125-137.

Lindsey, D.A., Langer, W.H., Cummings, L. S., and Shary, J.F., 1998a, Gravel deposits of the South Platte River Valley north of Denver, Colorado - Part A Stratigraphy and sedimentary structure: U.S. Geological Survey Open File report 98-148-A, 18p.

Lindsey, D.A., Langer, W.H., and Shary, J.F., 1998b, Gravel deposits of the South Platte River Valley north of Denver, Colorado - Part B - Quality of gravel deposits for aggregate: U.S. Geological Survey Open File report 98-148-B, 24 p.
Lindsey, D. A., and Shary, J. F., 1997, Field measures of gravel quality in the South Platte River north of Denver, Colorado: a pilot study: U.S. Geological Survey Open-File Report 97-451, 19 p.

Norman, D.K., Cederholm, C.J., and Lingley, W.S., Jr., 1998, Flood plains, salmon habitat, and sand and gravel mining: Washington Geology, v. 26, no. 2/3, p. 3-20.

Pettijohn, F. J., 1975, Sedimentary rocks (3rd ed.): New York, Harper and Row, 628 p.

Schneider, P.A.,Jr., and Hershey, L.A., 1961, Records and logs of selected wells and test hoiles, and chemical analyses of ground water in the lower Cache la Poudre River basin, Colorado: Colorado Water Conservation Board Basic Data Report n. 8, 63 p.

Schwochow, S.D., Shroba, R.R., and Wicklein, P.C., 1974a, Sand, gravel, and quarry aggregate resources Colorado Front Range counties: Colorado Geological Survey Special Publication 5-A, 43 p.

Schwochow, S.D., Shroba, R.R., and Wicklein, P.C., 1974b Atlas of sand, gravel, and quarry aggregate resources - Colorado Front Range counties: Colorado Geological Survey Special Publication 5-B, not paginated.

Scott, G.R., 1963, Quaternary geology and geomorphic history of the Kassler quadrangle, Colorado: U.S. Geological Survey Professional Paper 421-A, p. 1-70. Scott, G.R., 1963, Quaternary geology and geomorphic history of the Kassler quadrangle, Colorado: U.S. Geological Survey Professional Paper 421-A, p. 1-70.

Shelton, D.C., and Rogers, W.P., 1987, Environmental and engineering geology of the Windsor Study Area, Larimer and Weld Counties, Colorado: Colorado Geological Survey Environmental Geology, n. 6, 11 plates, 1:48,000 scale.

Wentworth, C. K., 1926, Methods of mechanical analysis of sediments: University of Iowa Studies in Natural History, v. 11, no. 11, 52 p. 
Table A1.--Particle-size data, sieved gravel samples, Cache la Poudre River valley. All samples from gravel beneath floodplain and lower (post-Piney Creek) terraces. Sample numbers refer to LaFarge Taft Hill (TH), Port-of-Entry (POE), Timnath (TM), Weitzel (W), Hall Irwin Windsor (HIW), Hall Irwin Greeley (HIG), LaFarge $35^{\text {th }}$ Street $(35 \mathrm{TH})$, and Greeley West $\left(25^{\text {th }}\right.$ Street, GW). Sample numbers ending in "T," upper gravel unit; "DG," dirty gravel (= upper unit); "B," lower gravel unit; "C," entire interval of gravel; no letter ending, entire interval of gravel. >, greater than. P25, first quartile size; P50, median size; P75, third quartile size; max. (maximum) size, estimated from cumulative frequency curve. MM, millimeters.

\begin{tabular}{|c|c|c|c|c|c|c|c|c|c|c|}
\hline \multirow{2}{*}{$\begin{array}{l}\text { SAMPLE } \\
\text { NUMBER }\end{array}$} & \multicolumn{6}{|c|}{ CUMULATIVE WEIGHT PERCENT } & \multicolumn{3}{|c|}{ PERCENTILES } & \multirow{2}{*}{$\begin{array}{l}\text { MAX. } \\
\text { SIZE } \\
(\mathrm{MM})\end{array}$} \\
\hline & $\begin{array}{c}>6 \\
\mathrm{INCH}\end{array}$ & $\begin{array}{c}>3 \\
\mathrm{INCH}\end{array}$ & $\begin{array}{l}>1.5 \\
\text { INCH }\end{array}$ & $\begin{array}{l}>3 / 4 \\
\mathrm{INCH}\end{array}$ & $\begin{array}{l}>3 / 8 \\
\mathrm{INCH}\end{array}$ & $\begin{array}{c}>3 / 16 \\
\text { INCH }\end{array}$ & $\begin{array}{l}\text { P25 } \\
\text { (MM) }\end{array}$ & $\begin{array}{l}\text { P50 } \\
\text { (MM) }\end{array}$ & $\begin{array}{l}\text { P75 } \\
\text { (MM) }\end{array}$ & \\
\hline $\mathrm{TH}-01$ & 12.5 & 40.7 & 50.2 & 63.0 & 69.2 & 73.8 & 4 & 40 & 110 & 200 \\
\hline $\mathrm{TH}-02$ & 5.7 & 28.0 & 48.2 & 59.5 & 65.8 & 70.5 & 3 & 35 & 80 & 180 \\
\hline $\mathrm{POE}-01 \mathrm{C}$ & 0.0 & 8.2 & 32.9 & 50.3 & 59.5 & 68.1 & 3 & 20 & 40 & 90 \\
\hline$P O E-01 T$ & 0.0 & 8.7 & 40.8 & 63.8 & 74.3 & 82.3 & 9 & 30 & 50 & 90 \\
\hline$\overline{P O E}-01 \mathrm{~B}$ & 0.0 & 18.6 & 41.3 & 58.0 & 66.2 & 71.0 & 3 & 25 & 65 & 150 \\
\hline $\mathrm{POE}-02 \mathrm{C}$ & 0.0 & 12.9 & 38.3 & 55.3 & 66.8 & 74.9 & 5 & 23 & 50 & 100 \\
\hline $\mathrm{POE}-02 \mathrm{~T}$ & 0.0 & 16.0 & 46.9 & 61.5 & 70.8 & 78.1 & 6 & 32 & 65 & 100 \\
\hline $\mathrm{POE}-02 \mathrm{~B}$ & 0.0 & 28.3 & 47.5 & 60.6 & 69.7 & 75.4 & 5 & 32 & 90 & 150 \\
\hline $\mathrm{POE}-03 \mathrm{C}$ & 0.0 & 21.4 & 46.6 & 66.6 & 77.7 & 83.7 & 11 & 32 & 70 & 150 \\
\hline $\mathrm{POE}-03 \mathrm{~T}$ & 0.0 & 0.0 & 28.8 & 50.9 & 64.2 & 73.0 & 4 & 20 & 35 & 75 \\
\hline$P O E-03 B$ & 0.0 & 9.8 & 41.5 & 57.3 & 67.7 & 75.6 & 5 & 25 & 50 & 90 \\
\hline $\mathrm{TM}-01 \mathrm{~T}$ & 0.0 & 8.2 & 34.1 & 49.1 & 59.1 & 68.1 & 3 & 18 & 58 & 94 \\
\hline $\mathrm{TM}-01 \mathrm{~B}$ & 0.0 & 15.1 & 50.9 & 64.4 & 72.7 & 80.5 & 8 & 40 & 60 & 100 \\
\hline $\mathrm{TM}-02 \mathrm{~T}$ & 0.0 & 8.8 & 35.9 & 45.3 & 53.4 & 60.0 & 1 & 12 & 58 & 94 \\
\hline $\mathrm{TM}-02 \mathrm{~B}$ & 0.0 & 11.9 & 54.3 & 67.6 & 74.8 & 81.0 & 9 & 40 & 56 & 90 \\
\hline$W-01 B$ & 0.0 & 10.7 & 44.1 & 61.2 & 69.2 & 75.9 & 5 & 30 & 58 & 92 \\
\hline $\mathrm{W}-02 \mathrm{~T}$ & 0.0 & 0.0 & 29.2 & 44.4 & 52.2 & 59.6 & 1 & 13 & 42 & 75 \\
\hline$W-02 B$ & 0.0 & 0.0 & 30.9 & 48.4 & 58.9 & 67.9 & 3 & 18 & 42 & 75 \\
\hline$W-03 B$ & 0.0 & 0.0 & 42.0 & 63.2 & 73.6 & 80.4 & 8 & 30 & 50 & 78 \\
\hline $\mathrm{HIW}-01 \mathrm{~T}$ & 0.0 & 0.0 & 18.3 & 38.1 & 47.7 & 58.4 & 2 & 8 & 30 & 70 \\
\hline $\mathrm{HIW}-01 \mathrm{~B}$ & 0.0 & 0.0 & 40.6 & 54.2 & 64.6 & 73.4 & 4 & 24 & 50 & 100 \\
\hline $\mathrm{HIW}-02 \mathrm{~T}$ & 0.0 & 0.0 & 15.9 & 41.1 & 56.1 & 65.4 & 2 & 12 & 30 & 55 \\
\hline $\mathrm{HIW}-02 \mathrm{~B}$ & 0.0 & 10.4 & 37.4 & 56.8 & 67.1 & 76.1 & 5 & 24 & 50 & 100 \\
\hline $\mathrm{HIG}-01 \mathrm{~T}$ & 0.0 & 0.0 & 20.5 & 52.2 & 62.9 & 70.7 & 3 & 20 & 35 & 60 \\
\hline HIG-01B & 0.0 & 0.0 & 30.1 & 50.1 & 59.6 & 67.9 & 2 & 20 & 42 & 100 \\
\hline $\mathrm{HIG}-02 \mathrm{~T}$ & 0.0 & 0.0 & 27.4 & 51.4 & 63.0 & 74.0 & 5 & 20 & 40 & 80 \\
\hline $\mathrm{HIG}-02 \mathrm{~B}$ & 0.0 & 0.0 & 23.3 & 40.5 & 52.1 & 66.3 & 3 & 11 & 35 & 90 \\
\hline $35 \mathrm{ST}-01 \mathrm{C}$ & 0.0 & 0.0 & 26.0 & 48.4 & 62.5 & 73.4 & 4 & 18 & 40 & 75 \\
\hline $35 \mathrm{ST}-01 \mathrm{~T}$ & 0.0 & 0.0 & 41.1 & 56.3 & 67.9 & 77.4 & 5 & 25 & 50 & 75 \\
\hline $35 \mathrm{ST}-01 \mathrm{~B}$ & 0.0 & 0.0 & 34.1 & 56.7 & 69.4 & 78.2 & 6 & 22 & 45 & 75 \\
\hline $\mathrm{GW}-01 \mathrm{C}$ & 0.0 & 0.0 & 23.6 & 45.3 & 57.6 & 68.5 & 3 & 15 & 38 & 75 \\
\hline $\mathrm{GW}-01 \mathrm{~T}$ & 0.0 & 0.0 & 18.4 & 39.3 & 51.7 & 63.7 & 2 & 10 & 30 & 65 \\
\hline $\mathrm{GW}-01 \mathrm{~B}$ & 0.0 & 0.0 & 30.1 & 50.4 & 61.5 & 70.8 & 3 & 20 & 40 & 100 \\
\hline $\mathrm{GW}-02 \mathrm{C}$ & 0.0 & 0.0 & 19.3 & 43.4 & 58.8 & 73.7 & 4 & 15 & 30 & 65 \\
\hline $\mathrm{GW}-02 \mathrm{~T}$ & 0.0 & 0.0 & 27.8 & 48.7 & 66.3 & 82.4 & 6 & 18 & 40 & 90 \\
\hline $\mathrm{GW}-02 \mathrm{~B}$ & 0.0 & 0.0 & 24.4 & 49.8 & 64.0 & 76.0 & 5 & 20 & 38 & 75 \\
\hline
\end{tabular}




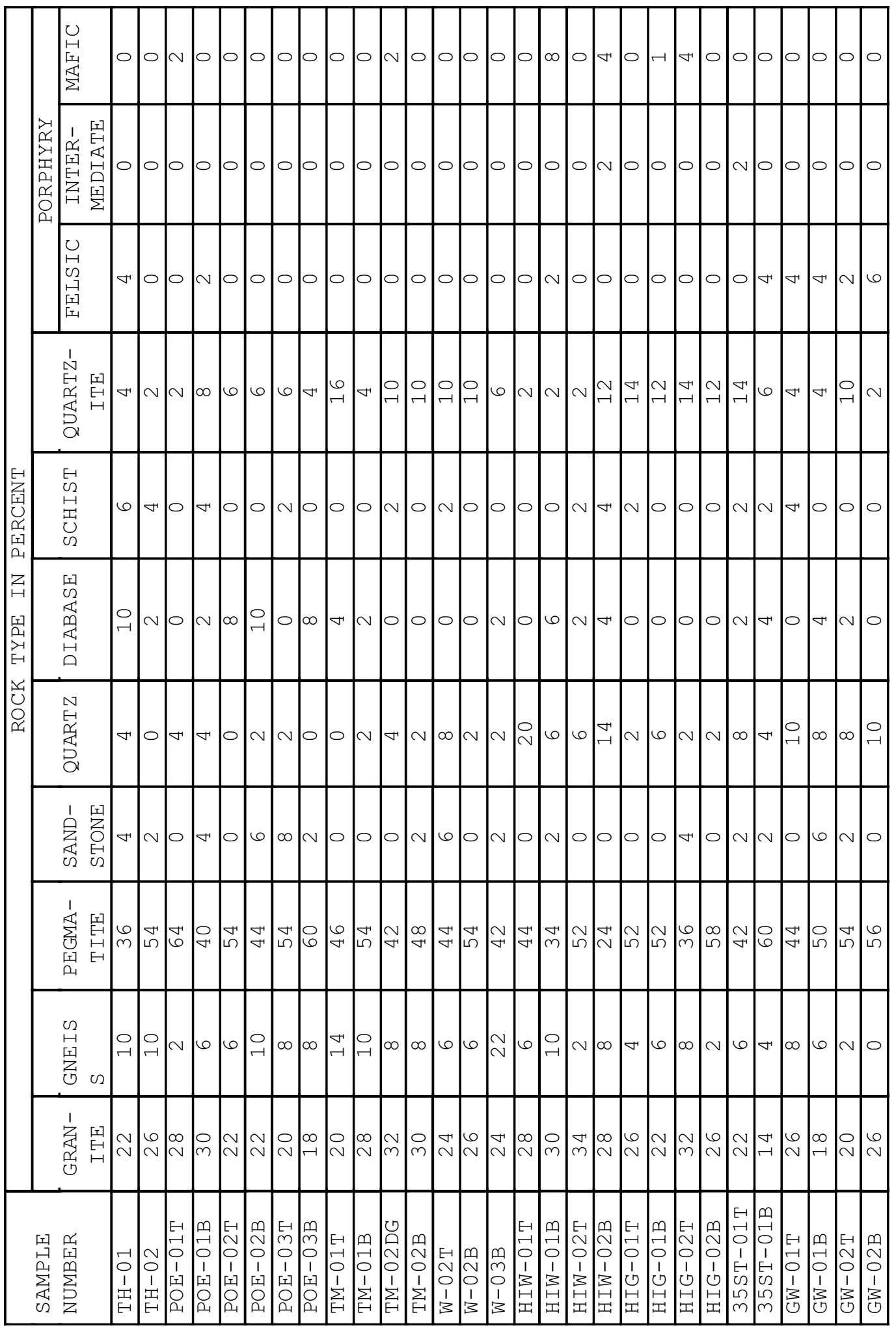


Table A3.--Gravel quality, Cache la Poudre River valley. All samples from gravel beneath floodplain and lower (post-Piney Creek) terraces. Percentages determined from classification of 50 pebbles, 3/4-1.5 inch size class. Sample numbers refer to LaFarge Taft Hill (TH), Port-ofEntry (POE), Timnath (TM), Weitzel (W), Hall-Irwin Windsor (HIW), Hall Irwin Greeley (HIG), LaFarge $35^{\text {th }}$ Street (35TH), and Greeley West $\left(25^{\text {th }}\right.$ Street, GW). Sample numbers ending in "T," upper gravel unit; "DG," dirty gravel (= upper unit); "B," lower gravel unit; no letter ending, entire interv al of gravel.

\begin{tabular}{|c|c|c|c|c|c|}
\hline \multirow{3}{*}{$\begin{array}{l}\text { SAMPLE } \\
\text { NUMBER }\end{array}$} & \multicolumn{5}{|c|}{ QUALITY IN PERCENT } \\
\hline & \multicolumn{3}{|c|}{ PHYS ICAL } & \multicolumn{2}{|c|}{ CHEMICAL } \\
\hline & FAIR & $\mathrm{POOR}$ & SATISFACTORY & DELETERIOUS & INNOCUOUS \\
\hline $\mathrm{TH}-01$ & 8 & 12 & 80 & 4 & 96 \\
\hline $\mathrm{TH}-02$ & 2 & 16 & 82 & 0 & 100 \\
\hline $\mathrm{POE}-01 \mathrm{~T}$ & 0 & 16 & 82 & 0 & 100 \\
\hline $\mathrm{POE}-01 \mathrm{~B}$ & 6 & 24 & 70 & 2 & 98 \\
\hline $\mathrm{POE}-02 \mathrm{~T}$ & 20 & 8 & 72 & 0 & 100 \\
\hline $\mathrm{POE}-02 \mathrm{~B}$ & 8 & 10 & 82 & 0 & 100 \\
\hline $\mathrm{POE}-03 \mathrm{~T}$ & 4 & 18 & 78 & 0 & 100 \\
\hline$P O E-03 B$ & 6 & 24 & 70 & 0 & 100 \\
\hline $\mathrm{TM}-01 \mathrm{~T}$ & 14 & 16 & 70 & 0 & 100 \\
\hline $\mathrm{TM}-01 \mathrm{~B}$ & 26 & 2 & 72 & 0 & 100 \\
\hline TM-02DG & 22 & 16 & 62 & 0 & 100 \\
\hline $\mathrm{TM}-02 \mathrm{~B}$ & 12 & 6 & 82 & 0 & 100 \\
\hline $\mathrm{W}-02 \mathrm{~T}$ & 24 & 2 & 74 & 0 & 100 \\
\hline $\bar{W}-02 \mathrm{~B}$ & 10 & 12 & 78 & 0 & 100 \\
\hline $\bar{W}-03 \mathrm{~B}$ & 24 & 8 & 68 & 0 & 100 \\
\hline $\mathrm{HIW}-01 \mathrm{~T}$ & 12 & 14 & 74 & 0 & 100 \\
\hline $\mathrm{HIW}-01 \mathrm{~B}$ & 10 & 8 & 82 & 2 & 98 \\
\hline $\mathrm{HIW}-02 \mathrm{~T}$ & 22 & 6 & 72 & 0 & 100 \\
\hline $\mathrm{HIW}-02 \mathrm{~B}$ & 16 & 8 & 76 & 2 & 98 \\
\hline $\mathrm{HIG}-01 \mathrm{~T}$ & 30 & 12 & 58 & 0 & 100 \\
\hline $\mathrm{HIG}-01 \mathrm{~B}$ & 32 & 8 & 60 & 0 & 100 \\
\hline $\mathrm{HIG}-02 \mathrm{~T}$ & 14 & 8 & 78 & 0 & 100 \\
\hline $\mathrm{HIG}-02 \mathrm{~B}$ & 20 & 2 & 78 & 0 & 100 \\
\hline $35 \mathrm{ST}-01 \mathrm{~T}$ & 22 & 10 & 68 & 2 & 98 \\
\hline $35 \mathrm{ST}-01 \mathrm{~B}$ & 4 & 18 & 78 & 4 & 96 \\
\hline $\mathrm{GW}-01 \mathrm{~T}$ & 12 & 12 & 76 & 4 & 96 \\
\hline $\mathrm{GW}-01 \mathrm{~B}$ & 4 & 12 & 84 & 4 & 96 \\
\hline $\mathrm{GW}-02 \mathrm{~T}$ & 14 & 14 & 72 & 2 & 98 \\
\hline $\mathrm{GW}-02 \mathrm{~B}$ & 0 & 14 & 86 & 6 & 94 \\
\hline
\end{tabular}


Table A4.--Gravel shape, Cache la Poudre River valley. All samples from gravel beneath floodplain and lower (post-Piney Creek) terraces. Percentages determined from measurement of 50 pebbles, 3/4-1.5 inch size class. $\mathrm{A}=$ long axis; $\mathrm{B}=$ intermediate axis; $\mathrm{C}=$ short axis. MEAN SPHERICITY $(\Psi)={ }^{3} \sqrt{ }\left(\mathrm{BC} / \mathrm{A}^{2}\right)$, measures degree of equidimensional shape; when $\mathrm{A}=\mathrm{B}=\mathrm{C}, \Psi=1$. Shape classified as spherical, disc-, rod-, and blade-shaped by criteria of Zingg (Pettijohn, 1975, fig. 3-18. Sample numbers refer to LaFarge Taft Hill (TH), Port-of-Entry (POE), Timnath (TM), Weitzel (W), Hall Irwin Windsor (HIW), Hall Irwin Greeley (HIG), LaFarge $35^{\text {th }}$ Street $(35 \mathrm{TH})$, and Greeley West $\left(25^{\text {th }}\right.$ Street, GW). Sample numbers ending in "T," upper gravel unit; "DG," dirty gravel (= upper unit); "B," lower gravel unit; no letter ending, entire interval of gravel.

\begin{tabular}{|l|c|c|c|c|c|c|c}
\hline SAMPLE & \multirow{2}{*}{$\begin{array}{c}\text { MEAN } \\
\text { NUMBER }\end{array}$} & MEAN & \multirow{2}{*}{$\begin{array}{c}\text { MEAN } \\
\text { C/B }\end{array}$} & SPHERICITY & \multicolumn{4}{|c}{ SHAPE CLASS IN PERCENT } \\
\cline { 5 - 7 } & & & & SPHERICAL & $\begin{array}{c}\text { DISC- } \\
\text { SHAPED }\end{array}$ & $\begin{array}{c}\text { ROD- } \\
\text { SHAPED }\end{array}$ & $\begin{array}{c}\text { BLADE- } \\
\text { SHAPED }\end{array}$ \\
\hline TH-01 & .740 & .630 & .692 & 28 & 42 & 20 & 10 \\
\hline TH-02 & .760 & .680 & .726 & 40 & 34 & 14 & 12 \\
\hline POE-01T & .760 & .660 & .715 & 34 & 42 & 16 & 8 \\
\hline POE-01B & .770 & .680 & .725 & 32 & 34 & 20 & 14 \\
\hline POE-02T & .730 & .680 & .696 & 26 & 38 & 26 & 10 \\
\hline POE-02B & .670 & .660 & .649 & 16 & 24 & 34 & 26 \\
\hline POE-03T & .750 & .690 & .724 & 48 & 34 & 14 & 4 \\
\hline POE-03B & .740 & .720 & .721 & 36 & 28 & 24 & 12 \\
\hline TM-01T & .720 & .660 & .691 & 30 & 36 & 20 & 14 \\
\hline TM-01B & .750 & .670 & .715 & 38 & 34 & 14 & 14 \\
\hline TM-02DG & .760 & .670 & .721 & 36 & 36 & 14 & 14 \\
\hline TM-02B & .750 & .670 & .714 & 26 & 48 & 20 & 6 \\
\hline W-02T & .740 & .690 & .714 & 34 & 30 & 22 & 14 \\
\hline W-02B & .750 & .680 & .719 & 42 & 32 & 18 & 8 \\
\hline W-03B & .760 & .620 & .704 & 26 & 46 & 12 & 16 \\
\hline HIW-01T & .740 & .700 & .723 & 38 & 32 & 20 & 10 \\
\hline HIW-01B & .750 & .650 & .709 & 30 & 42 & 12 & 16 \\
\hline HIW-02T & .750 & .710 & .728 & 32 & 38 & 26 & 4 \\
\hline HIW-02B & .720 & .660 & .690 & 30 & 38 & 20 & 12 \\
\hline HIG-01T & .770 & .640 & .715 & 28 & 42 & 14 & 16 \\
\hline HIG-01B & .760 & .620 & .703 & 28 & 52 & 10 & 10 \\
\hline HIG-02T & .710 & .640 & .672 & 14 & 48 & 24 & 14 \\
\hline HIG-02B & .730 & .640 & .692 & 26 & 44 & 20 & 10 \\
\hline 35 ST-01T & .690 & .670 & .676 & 32 & 28 & 22 & 18 \\
\hline 35ST-01B & .750 & .650 & .707 & 24 & 50 & 10 & 16 \\
\hline GW-01T & .730 & .640 & .694 & 26 & 40 & 14 & 20 \\
\hline GW-01B & .740 & .670 & .703 & 30 & 34 & 18 & 18 \\
\hline GW-02T & .780 & .650 & .727 & 32 & 54 & 14 & 0 \\
\hline GW-02B & .770 & .690 & .734 & 32 & 44 & 18 & 6 \\
\hline
\end{tabular}


Table A5.--Gravel roundness, Cache la Poudre River valley. All samples from gravel beneath floodplain and lower (post-Piney Creek) terraces. Percentages estimated by visual comparison of 50 pebbles, $3 / 4-1.5$ inch size class, by method of Pettijohn (1975, fig. 3-24). Mean roundness = class abundance $\mathrm{X}$ mid-point values of Pettijohn (1975, table 3-9). Classes defined as follows: A, angular; B, subangular; C, subrounded; D, rounded; E, well rounded. Sample numbers refer to LaFarge Taft Hill (TH), Port-of-Entry (POE), Timnath (TM), Weitzel (W), Hall Irwin Windsor (HIW), Hall Irwin Greeley (HIG), LaFarge $35^{\text {th }}$ Street (35TH), and Greeley West $\left(25^{\text {th }}\right.$ Street, GW). Sample numbers ending in "T," upper gravel unit; "DG," dirty gravel (= upper unit); "B," lower gravel unit; no letter ending, entire interval of gravel.

\begin{tabular}{|l|c|c|c|c|c|c|}
\hline \multirow{2}{*}{$\begin{array}{l}\text { SAMPLE } \\
\text { NUMBER }\end{array}$} & \multicolumn{2}{|c|}{ ROUNDNESS } & \multicolumn{1}{c|}{ CLASS } & \multicolumn{2}{c|}{ ANERAGE } \\
\cline { 2 - 6 } TH-01 & A & B & C & D ENT & E UNDNES \\
\hline TH-02 & 2 & 6 & 10 & 18 & 64 & .648 \\
\hline POE-01T & 4 & 6 & 2 & 26 & 62 & .649 \\
\hline POE-01B & 4 & 2 & 6 & 36 & 52 & .624 \\
\hline POE-02T & 6 & 12 & 20 & 22 & 40 & .525 \\
\hline POE-02B & 6 & 4 & 8 & 20 & 62 & .637 \\
\hline POE-03T & 4 & 12 & 16 & 26 & 42 & .545 \\
\hline POE-03B & 6 & 14 & 10 & 28 & 42 & .543 \\
\hline TM-01T & 10 & 10 & 14 & 20 & 46 & .545 \\
\hline TM-01B & 0 & 10 & 12 & 28 & 50 & .598 \\
\hline TM-02DG & 8 & 14 & 24 & 20 & 34 & .486 \\
\hline TM-02B & 4 & 8 & 26 & 32 & 30 & .503 \\
\hline W-02T & 6 & 8 & 16 & 16 & 54 & .586 \\
\hline W-02B & 2 & 12 & 14 & 28 & 44 & .563 \\
\hline W-03B & 2 & 8 & 24 & 20 & 46 & .562 \\
\hline HIW-01T & 10 & 14 & 18 & 28 & 30 & .477 \\
\hline HIW-01B & 4 & 2 & 18 & 44 & 32 & .542 \\
\hline HIW-02T & 6 & 16 & 30 & 26 & 22 & .440 \\
\hline HIW-02B & 0 & 10 & 16 & 32 & 42 & .566 \\
\hline HIG-01T & 4 & 16 & 20 & 34 & 26 & .478 \\
\hline HIG-01B & 2 & 12 & 16 & 44 & 26 & .505 \\
\hline HIG-02T & 2 & 6 & 32 & 42 & 18 & .469 \\
\hline HIG-02B & 2 & 0 & 10 & 44 & 44 & .606 \\
\hline 35ST-01T & 0 & 8 & 16 & 36 & 40 & .566 \\
\hline 35ST-01B & 4 & 2 & 12 & 26 & 56 & .625 \\
\hline GW-01T & 2 & 4 & 10 & 48 & 36 & .570 \\
\hline GW-01B & 2 & 4 & 16 & 28 & 50 & .601 \\
\hline GW-02T & 2 & 2 & 6 & 28 & 62 & .661 \\
\hline GW-02B & 2 & 6 & 10 & 26 & 56 & .624 \\
\hline
\end{tabular}


Table A6.--Sample sites, site symbols, and miles downstream from Taft-Hill gravel pit, Cache la Poudre River valley. All sample sites are in gravel pits operated by Lafarge, except as noted. Miles downstream were measured in a straight line. Five miles were added to miles downstream to yield downstream distance plotted in figures.

\begin{tabular}{|l|c|c|}
\hline SAMPLE & SITE & MILES \\
SITE & SYMBOL & DOWNSTREAM \\
\hline TAFT HILL & TH & 0.0 \\
\hline PORT-OF-ENTRY & POE & 7.1 \\
\hline TIMNATH & TM & 8.7 \\
\hline WEITZEL & W & 8.8 \\
\hline HALL IRWIN WINDSOR & HIW & 14.3 \\
\hline HALL IRWIN GREELEY & HIG & 20.4 \\
\hline 35 STREET & 35TH ST & 24.4 \\
\hline GREELEY WEST* & GW & 25.4 \\
\hline
\end{tabular}

$* 25^{\mathrm{TH}}$ Street 